\title{
Recruitment, Retention and the Minority Teacher Shortage
}

By

Richard Ingersoll

and

Henry May

A CPRE Research Report Co-Sponsored by:

The Consortium for Policy Research in Education, University of Pennsylvania

and

The Center for Educational Research in the Interest of Underserved Students, University of California, Santa Cruz

The Consortium for Policy Research in Education includes:

University of Pennsylvania Teachers College Columbia University

Harvard University Stanford University

University of Michigan University of Wisconsin-Madison Northwestern University 


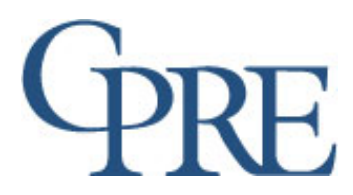

Established in 1985, CPRE unites researchers from seven of the nation's leading research institutions in efforts to improve elementary and secondary education through practical research on policy, finance, school reform, and school governance. CPRE studies alternative approaches to education reform to determine how state and local policies can promote student learning. The Consortium's member institutions are the University of Pennsylvania, Teachers CollegeColumbia University, Harvard University, Stanford University, the University of Michigan, University of Wisconsin-Madison, and Northwestern University.

In March 2006, CPRE launched the Center on Continuous Instructional Improvement (CCII), a center engaged in research and development on tools, processes, and policies intended to promote the continuous improvement of instructional practice. CCII also aspires to be a forum for sharing, discussing, and strengthening the work of leading researchers, developers and practitioners, both in the United States and across the globe.

To learn more about CPRE and CCII, visit our web sites at www.cpre.org and www.ccii-cpre.org.

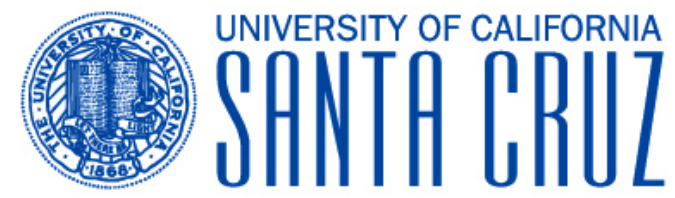

The Center for Educational Research in the Interest of Underserved Students (CERIUS) is a research unit in the Division of Social Sciences at the University of California, Santa Cruz. CERIUS develops, conducts, and disseminates educational research to improve the teaching and learning of the nation's increasingly diverse student population and the teachers who serve them. The Center is trans-disciplinary, drawing on studies of education from multiple theoretical perspectives. CERIUS serves as a hub to integrate the work of scholars who focus on three research domains: a) Teachers and Teacher Development, b) Literacy Education, and c) Science and Mathematics Education. Rodney Ogawa, Professor of Education, serves as the Center's Director. 


\title{
Consortium for Policy Research in Education
}

University of Pennsylvania | Teachers College Columbia University | Harvard University |

Stanford University | University of Michigan | University of Wisconsin-Madison | Northwestern University

\section{Recruitment, Retention and the Minority Teacher Shortage}

by

\author{
Richard M. Ingersoll and Henry May \\ of the
}

University of Pennsylvania

CPRE Research Report \# RR-69

September 2011

\section{A Research Report Co-Sponsored by}

The Consortium for Policy Research in Education, University of Pennsylvania

and

The Center for Educational Research in the Interest of Underserved Students,

University of California, Santa Cruz

This research was supported by Sally Hewlett and the Flora Family Foundation.

Opinions in this paper are those of the authors and do not necessarily reflect those of the Foundation, CPRE and its institutional partners, or The Center for Educational Research in the Interest of Underserved Students. Elizabeth Merrill provided valuable assistance with the data analysis. Earlier drafts of this paper were presented at conferences in June 2007 and June 2008 held by the Collaborative on Diversifying Teaching and Schooling at the Flora Family Foundation in Palo Alto, CA. Thanks are due to Betty Achinstein and Rodney Ogawa for helpful comments throughout the project. 


\section{Table of Contents}

\begin{tabular}{|lr|}
\hline Abstract & $i$ \\
\hline Introduction & 1 \\
\hline The Study & 5 \\
\hline Data and Methods & 8 \\
\hline Data & 8 \\
\hline Measures and Methods & 9 \\
\hline Results & 17 \\
\hline Trends in Minority Teacher Recruitment and Employment & 17 \\
\hline Trends in Minority Teacher Turnover & 23 \\
\hline The Determinants of Minority Teacher Turnover & 28 \\
\hline Individual, School, and Organizational Predictors of Minority Teacher Turnover & 31 \\
\hline Summary and Implications & 40 \\
\hline References & 47 \\
\hline Endnotes & 52 \\
\hline
\end{tabular}

\section{List of Figures}

\begin{tabular}{|l|r|}
\hline $\begin{array}{l}\text { Figure 1. Two Perspectives on the Causes and Consequences of Minority Teacher } \\
\text { Staffing Problems }\end{array}$ & 7 \\
\hline $\begin{array}{l}\text { Figure 2. Percentage Increase in Students and Teachers, by Race/ethnicity from 1987-88 } \\
\text { to 2007-08 }\end{array}$ & 20 \\
\hline $\begin{array}{l}\text { Figure 3. Of Different Types of Public Schools, Race/ethnicity of their Teaching Staff } \\
\text { (2003-2004) }\end{array}$ & 21 \\
\hline $\begin{array}{l}\text { Figure 4. Percent Annual Teacher Turnover, by Race/ethnicity of Teachers, } \\
\text { by Year }\end{array}$ & 26 \\
\hline $\begin{array}{l}\text { Figure 5. Numbers of Minority Teachers Entering and Leaving Teaching Before and } \\
\text { After the 2003-2004 School Year }\end{array}$ & 39 \\
\hline $\begin{array}{l}\text { Figure 6. Predicted Turnover Rates by Public School Organizational Conditions } \\
\text { Percentile }\end{array}$ & 24 \\
\hline
\end{tabular}


List of Tables

\begin{tabular}{|l|r|}
\hline Table 1. Definitions of Measures Utilized in the Regression Analysis & 14 \\
\hline Table 2. Descriptive Statistics for Independent Variables Used in Regression Analysis & 15 \\
\hline $\begin{array}{l}\text { Table 3. Trends in the Nation's Population, K-12 Student Enrollment, and the K-12 } \\
\text { Teaching Force, by Race/Ethnicity }\end{array}$ & 19 \\
\hline $\begin{array}{l}\text { Table 4. Of Minority and White Public School Teachers, Percentage Employed in } \\
\text { Different Types of Schools, (2003-2004) }\end{array}$ & 20 \\
\hline $\begin{array}{l}\text { Table 5. Percentage Public School Teachers Reporting Less Positive Organizational } \\
\text { Conditions, By Type of School (2003-04) }\end{array}$ & 22 \\
\hline $\begin{array}{l}\text { Table 6. Percentage Annual Teacher Migration and Attrition, by Race/ethnicity of } \\
\text { Teachers, and by Year }\end{array}$ & 24 \\
\hline $\begin{array}{l}\text { Table 7. Of Public School Teachers Who Moved to Other Schools, Percentage } \\
\text { Reporting Various Categories of Reasons Were Very or Extremely Important, by } \\
\text { Race/ethnicity of Teachers, (2004-05) }\end{array}$ & 29 \\
\hline $\begin{array}{l}\text { Table 8. Of Public School Teachers Who Left Teaching, Percentage Reporting Various } \\
\text { Categories of Reasons Were Very or Extremely Important, by Race/ethnicity of } \\
\text { Teachers (2004-05) }\end{array}$ & 33 \\
\hline $\begin{array}{l}\text { Table 9. Logistic Regression Analysis of the Likelihood of Public School Minority } \\
\text { and White Teacher Turnover }\end{array}$ & 36 \\
\hline $\begin{array}{l}\text { Table 10. Logistic Regression Analysis of the Likelihood of Public School Minority } \\
\text { and White Teacher Turnover }\end{array}$ & 29 \\
\hline
\end{tabular}




\begin{abstract}
This study examines and compares the recruitment and retention of minority and White elementary and secondary teachers and attempts to empirically ground the debate over minority teacher shortages. The data we analyze are from the National Center for Education Statistics' nationally representative Schools and Staffing Survey and its longitudinal supplement, the Teacher Follow-up Survey.
\end{abstract}

Our data analyses show that a gap continues to persist between the percentage of minority students and the percentage of minority teachers in the U.S. school system. But this gap is not due to a failure to recruit new minority teachers. Over the past two decades, the number of minority teachers has almost doubled, outpacing growth in both the number of White teachers and the number of minority students. Minority teachers are also overwhelmingly employed in public schools serving high-poverty, high-minority and urban communities. Hence, the data suggest that widespread efforts over the past several decades to recruit more minority teachers and employ them in hard-to-staff and disadvantaged schools have been very successful.

This increase in the proportion of teachers who are minority is remarkable because the data also show that over the past two decades, turnover rates among minority teachers have been significantly higher than among White teachers. Moreover, though schools' demographic characteristics appear to be highly important to minority teachers' initial employment decisions, this does not appear to be the case for their later decisions to stay or depart. Neither a school's poverty-level student enrollment, a school's minority student enrollment, a school's proportion of minority teachers, nor whether the school was in an urban or suburban community was consistently or significantly related to the likelihood that minority teachers would stay or depart, after controlling for other background factors. 
In contrast, organizational conditions in schools were strongly related to minority teacher departures. Indeed, once organizational conditions are held constant, there was no significant difference in the rates of minority and White teacher turnover. The schools in which minority teachers have disproportionately been employed have had, on average, less positive organizational conditions than the schools where White teachers are more likely to work, resulting in disproportionate losses of minority teachers. The organizational conditions most strongly related to minority teacher turnover were the level of collective faculty decision-making influence and the degree of individual classroom autonomy held by teachers; these factors were more significant than were salary, professional development or classroom resources. Schools allowing more autonomy for teachers in regard to classroom issues and schools with higher levels of faculty input into school-wide decisions had far lower levels of turnover. 


\section{Introduction}

Over the past several decades, there has been much concern over shortages of minority school teachers. Numerous scholars and commentators have argued that there is a growing mismatch between the degree of racial/ethnic diversity in the nation's student population and the degree of diversity in the nation's elementary and secondary teaching force (for reviews, see Quiocho \& Rios, 2000; Torres et al., 2004; Villegas \& Lucas, 2004; Zumwalt \& Craig, 2005). Typically, critics have held that as the nation's population, and in turn the nation's student body, has grown more diverse, the teaching force has not kept pace. Some go further-arguing that the teaching force has changed in the opposite direction, becoming even less diverse and more homogeneously White.

Critics make three related arguments for why this mismatch is detrimental and why increasing the racial/ethnic diversity of the teaching force would be beneficial. The first focuses on demographic parity. This argument holds that minority teachers are important as role models for both minority and White students. The underlying assumption is that the racial/ethnic makeup of the teaching force should reflect that of the student population, and that of the larger society. With increasing racial/ethnic diversity in the larger society, proponents hold, there is accordingly a growing need for more minority teachers as role models in schools (e.g., Carnegie Forum on Education and the Economy, 1986; American Association of Colleges of Teacher Education, 1999; Banks, 1995; Cochran-Smith, 2004; Dilworth, 1992; Kirby et al., 1999).

A second related argument focuses on what is often called "cultural synchronicity" (Irvine, 1988, 1989). This view holds that minority students benefit from being taught by minority teachers, because minority teachers are likely to have "insider knowledge” due to similar life experiences and cultural backgrounds. The assumption is that synchronicity is a 
valuable resource in teaching and learning (Villegas \& Irvine, 2010; Gandara \& Maxwell-Jolley, 2000; Valencia, 2002; Haycock, 2001; Foster, 1994; Achinstein \& Aguirre, 2008). Proponents of this view cite a growing number of empirical studies showing that minority teachers have a positive impact on various outcomes for minority students (for a review, see Villegas \& Lucas, 2004).

A third related argument concerns teacher shortages in general. Minority teachers not only are likely to be well suited to teach minority students, this view holds, but they are also likely to be motivated by a "humanistic commitment" to making a difference in the lives of disadvantaged students. In turn, this argument holds, minority teachers are more likely than nonminority candidates to seek employment in schools serving predominantly minority student populations, often in low-income, urban school districts (e.g., Foster, 1997; Haberman, 1996; Murnane et al., 1991; Ladson-Billings, 1995; Quiocho \& Rios, 2000). Research has shown that these same kinds of schools—urban, poor public schools serving minority students— disproportionately suffer from general teacher shortages (e.g., Liu et al., 2008). Hence, diversification of the teaching force in this view is a solution to the more general problem of teacher shortages in disadvantaged schools.

As a result of these various factors—a lack of minority teacher role models, insufficient cultural synchronicity between teachers and minority students, and a general dearth of qualified teachers in disadvantaged schools—critics have concluded that the minority teacher shortage has resulted in unequal access to adequately qualified teachers and, hence, to quality teaching, in poor, urban public schools serving minority students. Unequal access to educational resources, such as qualified teachers, has long been considered a primary cause of the stratification of educational opportunity and, in turn, the achievement gap and, ultimately, unequal occupational 
outcomes for disadvantaged students (e.g., Dreeben \& Gamoran, 1986; Oakes, 1985, 1990;

Rosenbaum, 1976; Wilson, 1996).

Critics have identified several factors behind these minority teacher staffing problems (for reviews, see Zumwalt \& Craig, 2005; Villegas \& Irvine, 2010). These factors concern different stages in the pipeline of supply into the teaching occupation. One prominent factor, this view holds, has been that minority student underachievement in elementary and secondary education has resulted in fewer minority students entering the post-secondary level, and lower graduation rates for those who do enter college (e.g., Banks, 1995). In turn, as career and employment options available to minorities have broadened, a shrinking share of this shrinking number of minority college graduates have entered teaching. Finally, this view holds, when minority candidates do seek to enter teaching, the growth of occupational entry tests, coupled with lower pass rates on these tests by minority teaching candidates, has meant that fewer minority candidates are successful.

The prevailing policy response to these minority teacher staffing problems has been to attempt to increase the supply of minority teachers (see, e.g., Hirsch, Koppich, \& Knapp, 2001; Feistritzer, 1997; Liu et al., 2008; Rice, Roellke, Sparks, \& Kolbe, 2008). Over the past several decades, organizations such as the Education Commission of the States (2003), the American Association of Colleges of Teacher Education (1999), and the National Educational Association (National Collaborative on Diversity in the Teaching Force, 2004) have advocated and implemented a wide range of initiatives designed to recruit minority candidates into teaching. Beginning in the late 1980s, the Ford Foundation, the DeWitt Wallace-Readers’ Digest Fund and other foundations committed substantial funding to recruiting and preparing minority teachers. These efforts have included future educator programs in high schools, partnerships between 
community colleges with higher minority student enrollments and four-year colleges with teacher education programs, career ladders for paraprofessionals already in the school system, and alternative certification programs (e.g., Zeichner, 1996; Zeichner \& Gore, 1990; Shen, 1998; Clewell \& Villegas, 2001; Lau et al., 2007). Many of these initiatives have been designed to recruit minority teachers to teach in schools serving predominantly minority student populations, often in low-income, urban school districts. Some of these initiatives have been designed to recruit male minority teachers—often considered the group in shortest supply (e.g., Lewis, 2006; Norton, 2005). By 2005, 36 states had minority teacher recruitment policies (Villegas \& Irvine, 2010).

Nonetheless, there has been a surprising dearth of empirical investigation, especially using nationally representative data, into how the minority teaching force has changed over recent decades, whether there is still insufficient employment of minorities in teaching, and where minority teacher staffing problems originate. Underlying most of the research, commentary and policy on this issue has been the assumption, largely untested, that minority teacher staffing problems are rooted in the front end of the teacher supply pipeline. The assumption has been that an inadequate initial supply, coupled with barriers to entry, are the main reasons that insufficient numbers of minority teachers are employed. Thus attention has tended to focus on identifying obstacles to recruiting minority candidates into teaching and, in turn, developing strategies to overcome these obstacles (Villegas \& Lucas, 2004; Villegas \& Irvine, 2010).

In contrast, little attention has been paid to where minority teachers tend to be employed, what happens to minority teachers once they are employed, or to the role in these staffing problems of the organizations that employ teachers. Moreover, relatively less attention has been 
paid to the exit end of the pipeline and the role of teacher turnover - the departures of teachers from schools_-in these shortages and staffing problems (Rice et al., 2008). As a recent review concluded, empirical research on minority teacher turnover has been limited, has had mixed findings, and, in general, has been inadequate to help us address the magnitude, determinants and consequences of minority teacher turnover, or understand the implications of retention and turnover for shortages (Achinstein et al., 2010). This study begins to address these gaps.

\section{The Study}

This study uses nationally representative data to empirically ground the debate over minority teacher shortages. We examine trends in the recruitment, employment and retention of minority teachers, using several sets of research questions:

\section{Trends in Minority Teacher Recruitment and Employment}

In recent decades, what changes have there been in the numbers of minority students and numbers of minority teachers in the school system, and how does this compare with White students and teachers? Is there more or less racial/ethnic diversity in the teaching force? Have there been changes in the student-to-teacher race/ethnicity gap, that is, the difference between the percentage of minority students and the percentage of minority teachers in the school system? What is the distribution of teachers across the school system, by their race/ethnicity? Are minority teachers more likely than White teachers to be employed in schools serving highpoverty, urban, and high-minority student populations? How do the organizational and working conditions of minority teachers' schools compare to those of White teachers? 


\section{Trends in Minority Teacher Turnover}

In recent decades, what have been the rates and magnitude of minority teacher turnoverboth those moving between schools and those leaving teaching altogether? How does this compare to White teachers? What is the role of minority teacher turnover in the staffing problems of schools and in the minority teacher shortage?

\section{3.) The Determinants of Minority Teacher Turnover}

What are the reasons behind the turnover of teachers and does this differ by their race/ethnicity? What proportion of minority and White teacher turnover is due to retirement? Are the demographic characteristics of schools associated with the departures of teachers, and does this differ by the race/ethnicity of teachers? Are minority teachers less likely than White teachers to depart from schools serving high-poverty, urban, and high-minority student populations? What role do job and organizational conditions (e.g., salary levels, administrative support, faculty decision making influence, teachers' classroom autonomy, student discipline and behavioral problems, availability of classroom instructional resources, teacher professional development) play in the turnover of minority teachers, and how does this compare with White teachers?

Our theoretical perspective, drawn from organizational theory and from the sociology of organizations, occupations and work, is that teacher employment and staffing issues, like those in other industries, cannot be fully understood without "putting the organization back" into the analysis (cf. Stolzenberg, 1978; Baron \& Bielby, 1980; Kalleberg, 1989; Hirsch \& Lounsbury, 1997). Employee supply, demand, and turnover are central issues in organizational theory and research (e.g., Price, 1977, 1989; Hom \& Griffeth, 1995). However, there have been few efforts to apply this theoretical perspective to understanding employee staffing problems in education. 
By adopting this perspective, we seek to discover the extent to which staffing problems in schools can be usefully reframed from macro-level issues, involving inexorable societal demographic trends, to organizational-level issues, involving policy-amenable aspects of particular districts and schools. The central premise of our study is that fully understanding minority teacher shortages and staffing problems requires not only examining the supply pipeline before employment, but also examining what happens to teachers once they are employed and examining the organizational characteristics of the workplaces where teachers are employed (see

Figure 1).

Figure 1: Two Perspectives on the Causes and Consequences of Minority Teacher Staffing Problems

\section{The minority teacher shortage thesis:}

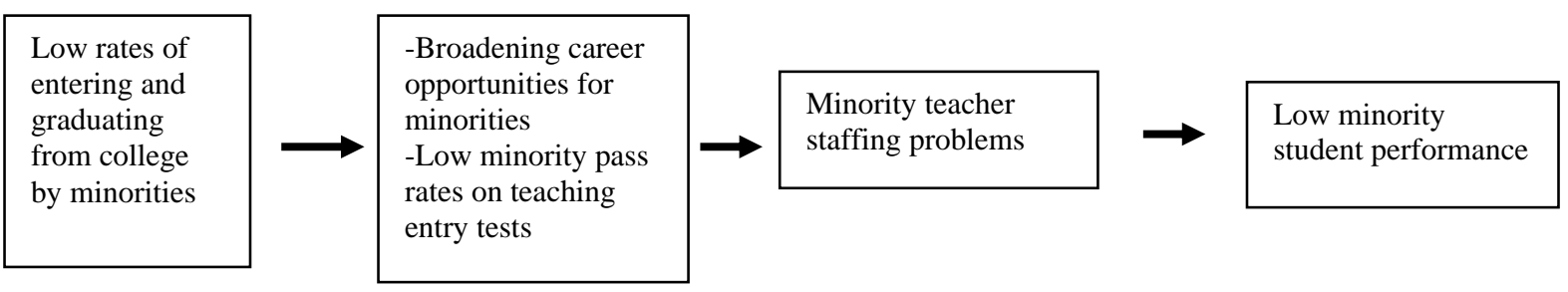

\section{An organizational perspective:}

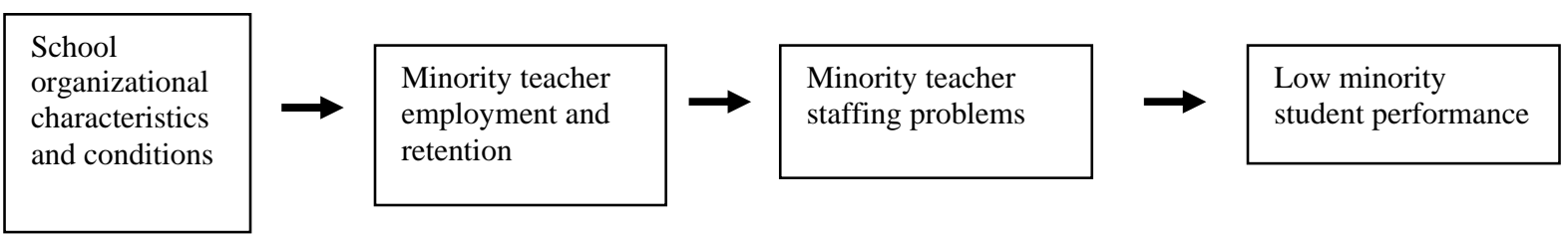

Our focus in this study is the relationships depicted on the left side of the organization perspective panel in Figure 1-identifying the characteristics and conditions of schools that are 
related to minority teacher employment and turnover and documenting the role that minority teacher turnover plays in minority teacher staffing problems. Note that our focus is not on the relationships depicted on the right side of Figure 1, or whether teaching force diversification is positive or negative, or its impact on achievement.

In the next section, we describe our data sources and define key terms and measures. In the following sections, we present our results sequentially for each of our three research questions. We then conclude by discussing the implications of our findings for understanding and addressing the minority teacher shortage.

\section{Data and Methods}

\section{Data}

The data for this study come from the National Center for Education Statistics’ (NCES) nationally representative Schools and Staffing Survey (SASS) and its supplement, the Teacher Followup Survey (TFS). This is the largest and most comprehensive data source available on the staffing, occupational, and organizational aspects of elementary and secondary schools. The U.S. Census Bureau collects the SASS data for NCES from a random sample of schools stratified by state, public/private sector, and school level (for information on SASS, see NCES, 2005). There have been six SASS cycles to date-1987-88; 1990-91; 1993-94; 1999-00; 2003-04; 2007-08. Each cycle of SASS includes separate (but linked) questionnaires for school and district administrators and for a random sample of teachers in each school. After 12 months, the same schools are again contacted, and all those in the original teacher sample who had departed from their school are given a second questionnaire to obtain information on their departures. The TFS comprises this latter group, along with a representative sample of those who stayed in their 
teaching jobs. Unlike most previous data sources on teacher turnover, the TFS is large, comprehensive, and nationally representative, and it includes the reasons teachers themselves give for their departures along with a wide range of information on the characteristics and conditions of the schools that employ teachers. It also is unusual in that it does not focus solely on a particular subset of separations, but includes all types of departures. (For information on the TFS, see Chandler et al., 2004.)

Our analysis uses data from all six cycles of SASS/TFS to examine trends. We focus on the 2003-04 SASS and the 2004-05 TFS for our primary analyses. The 2004-05 TFS has the advantage of having a larger sample size than the more recent 2008-09 cycle of TFS. The 200304 SASS sample comprises 43,358 White and 7,865 minority elementary and secondary teachers. The 2004-05 TFS sample comprises 6,118 White and 1,311 minority elementary and secondary teachers. This analysis uses data weighted to compensate for the over- and undersampling of the complex stratified survey design. Each observation is weighted by the inverse of its probability of selection in order to obtain unbiased estimates of the national population of schools and teachers in the year of the survey.

\section{Measures and Methods}

Our classification of minority teachers and White teachers is based on the SASS teacher respondent's self identification of their race/ethnicity in SASS questionnaires. Non-minority refers to White, non-Hispanic. Minority includes those self identifying as Black or African American, Asian, American Indian/Alaska Native, native Hawaiian/Pacific Islander, Hispanic and multiple races. In 2003-04, the percentages for these minority groups were, respectively, $7.4 \%, 1.4 \%, .6 \%, .2 \%, 6 \%$, and $.7 \%$. These groups are, of course, not homogeneous, between or within, hence drawing conclusions about minority teachers as a whole runs the risk of 
overgeneralizing. However, underlying our study is the assumption that patterns across subgroups can be informative. In a companion study, Connor (2011) focused specifically on Black and African American teachers, comparing them to White teachers. His findings on turnover were similar to those reported in our study.

Our analysis has two stages. In the first stage, we present mostly descriptive statistics to address our three research questions. In the second stage, we follow up with a detailed multiple logistic regression analysis of the predictors of turnover to further address the third research question. Below, we describe these stages of our analysis.

In the first stage, we examine data on trends in the relative numbers of minority and White students and minority and White teachers, data on differences in the types of schools in which minority and White teachers are employed, and data on trends in the turnover rates of minority and White teachers.

Research on teacher turnover has often focused solely on those leaving the occupation altogether, here referred to as teacher attrition, and has often de-emphasized those who transfer or move to different teaching jobs in other schools, here referred to as teacher migration. The logic is that teacher migration is a less significant form of turnover because it does not increase or decrease the overall supply of teachers, as do retirements and career changes and, hence, does not contribute to overall shortages. From a systemic level of analysis, this is probably correct. However, from the organizational perspective of this study, employee migration is as relevant as employee attrition. The premise underlying our perspective is that whether those departing are moving to a similar job in another organization or leaving the occupation altogether, their departures similarly impact and are impacted by the organization. For this same reason, the distinction between attrition and migration is rarely noted in the larger literature on employee 
turnover, and research on other occupations and organizations almost always includes both (see, e.g., Price, 1977). We also include both, and we examine them both separately and together.

We then examine the reasons teachers themselves give for their migration and attrition, drawn from sets of items in the TFS questionnaire that asked teacher-respondents to indicate the importance of various factors for their departures. Self-report data such as these are useful because those departing are, of course, often in the best position to know why they are leaving. But such data are also based on subjective attributions by those who departed, introducing possible attribution bias. Moreover, the items are often general (e.g., "dissatisfied with teaching”), and do not indicate which aspects of teaching, or of schools, are related to turnover.

To address these limits, we follow up in our second stage with a regression analysis that examines the association with turnover of a more specific set of school organizational characteristics/conditions, based on data from the full and larger sample of respondents in the 2003-04 SASS (including both those who stayed and those who later departed). Because we establish in the first stage of our analysis that over $90 \%$ of minority school teachers are employed in public schools, and the majority of these are concentrated in schools serving high-poverty, high-minority or urban communities, we focus on the public sector in our regression models. In the regression models, the dependent variable — teacher turnover—is based on whether each teacher remained with the school, moved to another school, or left teaching within one year after the 2003-04 SASS administration. The TFS includes only about $12 \%$ of teachers from the original SASS sample. To increase the sample size for our regression analyses, we combined the TFS measure of turnover with another measure of turnover collected from school principals (the teacher Status variable) for the entire SASS public school teacher sample, increasing our effective sample size from about 5,300 to 43,000 teachers. ${ }^{\mathrm{i}}$ 
We cumulatively examine three groups of predictors of turnover: teacher characteristics, school characteristics, and organizational conditions. Table 1 defines for these variables. Table 2 provides mean teacher characteristics, school characteristics, and organizational conditions associated with the teachers in the combined SASS/TFS sample.

Following previous research on teacher turnover, in the regression models we include control variables for two key individual teacher characteristics: gender and age. Because it has been found to have a U-shaped relationship to turnover (Ingersoll, 2001), we transform age into a three-category set of dummy variables—younger (less than 30), middle-aged (31-50), and older (greater than 50).

Following previous research on school organization (e.g., Bryk et al., 1990; Chubb \& Moe, 1990; Coleman \& Hoffer, 1987), in the regression models we include, as independent variables, school characteristics typically found to be important in this literature: school level and school size.

To examine the role of school demographic characteristics, we also include measures of whether the school is urban, rural, or suburban, the proportion of each school's student population at or below the poverty level (i.e., eligible for free or reduced lunch), the proportion of each school's student population that is minority, and proportion of the school faculty that is minority. Because these demographic factors are often highly inter-correlated and confounded, we estimate their effects both separately and simultaneously in conjunction to discern the extent to which they are independent or redundant.

Finally, after controlling for the above teacher and school factors, we focus on the relationship to turnover of eight key aspects of the organizational character and conditions in schools: teacher salary, student discipline problems, school leadership and support, school 
resources, faculty school-wide decision-making influence, teacher classroom autonomy, teacher professional development activities focused on student discipline and classroom management, and professional development activities focused on the teacher's subject-area content. This study does not attempt to provide a comprehensive analysis of all the many aspects of schools that may impact the turnover of minority teachers. We focus on this set of eight particular characteristics of schools because they have long been considered among the important aspects of effective school organization (see, e.g., Goodlad, 1984; Coleman \& Hoffer, 1987; Grant, 1988; Chubb \& Moe, 1990; Bryk et al., 1990), are ostensibly policy amenable, and are available from our data source.

Unlike most empirical analyses, which use either individual teacher's salaries or the school's mean teacher salary, we use the normal yearly base salary for teachers at the highest step on the district or school salary schedule because it better assesses differences in the organizational-level compensation structure. ${ }^{\text {ii }}$ As defined in Table 1, for the other seven measures of organization conditions we use school means of teachers' responses to sets of items in the teacher questionnaire.

This second stage of the analysis examines whether the likelihood that individual teachers will move from or leave their teaching jobs is related to the above measures of school organizational characteristics and conditions, while controlling for individual-level characteristics of teachers and school-level characteristics. Because different school organizational conditions are often interrelated, and their relationship to turnover is possibly confounded, we estimate the coefficients for each measure of school organizational conditions both in separate models and simultaneously. 
Table 1. Definitions of Measures Utilized in the Regression Analysis

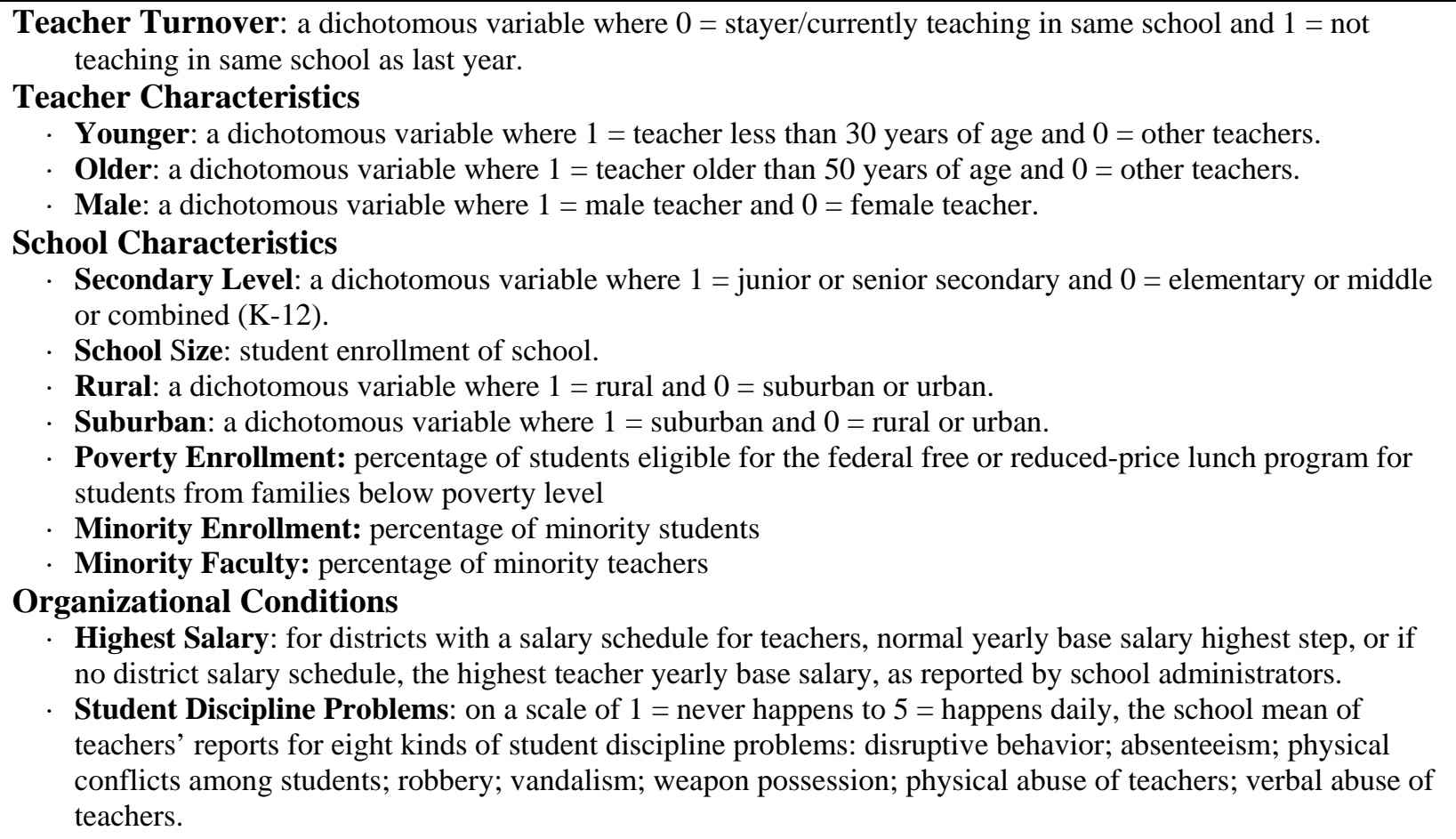

- School Leadership Support: on a scale of $1=$ strongly disagree to $4=$ strongly agree, the school mean of teachers' reports for four items: principal communicates expectations; administration is supportive; principal enforces rules for student discipline; principal communicates objectives; staff are recognized for job well done.

- School Resources: on a scale of 1 = strongly disagree to $4=$ strongly agree, the school mean of teachers' reports for one item: necessary materials such as textbooks, supplies and copy machines are available as needed by the staff.

- Faculty Influence: on a scale of 1 = none to 4 = a great deal, the school mean of collective school-wide faculty influence over seven areas: student performance standards; curriculum; content of in-service programs; evaluating teachers; hiring teachers; school discipline policy; deciding spending of budget.

- Teacher Autonomy: on a scale of $1=$ none to $4=$ a great deal, the school mean of individual teacher's control in their classroom over six areas: selecting textbooks and other instructional materials; selecting content, topics and skills to be taught; selecting teaching techniques; evaluating and grading students; determining the amount of homework to be assigned; disciplining students.

- Discipline-Focused Professional Development: on a scale of $1=$ not receive or not useful to $4=$ very useful, the school mean of teachers' reports of the usefulness of any professional development activities that focused on student discipline and management in the classroom.

- Content-Focused Professional Development: on a scale of $1=$ not receive or not useful to $4=$ very useful, the school mean of teachers' reports of the usefulness of any professional development activities that focused on the content of the subjects they taught.

We used factor analysis (with varimax rotation method) to evaluate our indices of student discipline problems, school leadership, faculty influence and teacher autonomy. We considered item loadings of at least .4 necessary for inclusion in a factor. No items loaded on more than one factor. Each factor had high internal consistency $(\mathrm{a}>\mathrm{.7})$.

The measures of student discipline problems, leadership, resources, faculty influence, teacher autonomy and professional development are all school means of the reports of the larger total SASS teacher sample for each school and not limited to the reports of those in the smaller TFS sample. 
Table 2. Descriptive Statistics for Independent Variables Used in Regression Analysis

\begin{tabular}{|c|c|c|c|}
\hline \multirow[b]{2}{*}{ Categorical Predictor Variables } & \multicolumn{3}{|c|}{ Proportion } \\
\hline & All Teachers & White & Minority \\
\hline \multicolumn{4}{|l|}{ Teacher Characteristics } \\
\hline Younger & .17 & .16 & .17 \\
\hline Older & .30 & .31 & .25 \\
\hline Male & .25 & .25 & .24 \\
\hline \multicolumn{4}{|l|}{ School Characteristics } \\
\hline Secondary Level & .30 & .30 & .28 \\
\hline Rural & .19 & .21 & .11 \\
\hline \multirow[t]{2}{*}{ Suburban } & .52 & .55 & .39 \\
\hline & \multicolumn{3}{|c|}{$\begin{array}{c}\text { Mean } \\
\text { (Std. Dev.) }\end{array}$} \\
\hline Continuous Predictor Variables & All Teachers & White & Minority \\
\hline \multicolumn{4}{|l|}{ School Characteristics } \\
\hline School Size (in 100s) & $\begin{array}{c}8.04 \\
(6.07)\end{array}$ & $\begin{array}{c}7.87 \\
(5.94)\end{array}$ & $\begin{array}{c}8.9 \\
(6.59)\end{array}$ \\
\hline Poverty Enrollment (in 10s) & $\begin{array}{c}4.12 \\
(2.93)\end{array}$ & $\begin{array}{c}3.7 \\
(2.73)\end{array}$ & $\begin{array}{c}6.22 \\
(2.99)\end{array}$ \\
\hline Minority Enrollment (in 10s) & $\begin{array}{c}4.12 \\
(2.93)\end{array}$ & $\begin{array}{l}3.54 \\
(3.3)\end{array}$ & $\begin{array}{c}7.49 \\
(2.98)\end{array}$ \\
\hline Minority Faculty (in 10s) & $\begin{array}{c}15.5 \\
(22.9)\end{array}$ & $\begin{array}{c}10.1 \\
(16.3)\end{array}$ & $\begin{array}{c}42.83 \\
(30.62)\end{array}$ \\
\hline \multicolumn{4}{|l|}{$\underline{\text { Organizational Conditions }}$} \\
\hline Highest Salary (in 10,000s) & $\begin{array}{c}6.08 \\
(1.30)\end{array}$ & $\begin{array}{c}6.06 \\
(1.33)\end{array}$ & $\begin{array}{c}6.20 \\
(1.18)\end{array}$ \\
\hline Student Discipline Problems (scale 1-5) & $\begin{array}{c}2.29 \\
(0.71)\end{array}$ & $\begin{array}{l}2.28 \\
(0.7)\end{array}$ & $\begin{array}{c}2.35 \\
(0.73)\end{array}$ \\
\hline School Leadership Support (scale 1-4) & $\begin{array}{c}3.32 \\
(0.65)\end{array}$ & $\begin{array}{c}3.32 \\
(0.65)\end{array}$ & $\begin{array}{c}3.33 \\
(0.67)\end{array}$ \\
\hline School Resources (scale 1-4) & $\begin{array}{c}3.14 \\
(0.89)\end{array}$ & $\begin{array}{c}3.17 \\
(0.87)\end{array}$ & $\begin{array}{c}3.0 \\
(0.95)\end{array}$ \\
\hline Faculty Influence (scale 1-4) & $\begin{array}{c}2.21 \\
(0.61)\end{array}$ & $\begin{array}{l}2.21 \\
(0.6)\end{array}$ & $\begin{array}{c}2.24 \\
(0.68)\end{array}$ \\
\hline Teacher Autonomy (scale 1-4) & $\begin{array}{c}3.38 \\
(0.52)\end{array}$ & $\begin{array}{c}3.40 \\
(0.51)\end{array}$ & $\begin{array}{c}3.3 \\
(0.54)\end{array}$ \\
\hline Discipline-Focused Prof. Dev. (scale 1-4) & $\begin{array}{c}1.77 \\
(1.04)\end{array}$ & $\begin{array}{c}1.73 \\
(1.01)\end{array}$ & $\begin{array}{c}1.97 \\
(1.14)\end{array}$ \\
\hline Content-Focused Prof. Dev. (scale 1-4) & $\begin{array}{c}2.64 \\
(1.03)\end{array}$ & $\begin{array}{c}2.60 \\
(1.02)\end{array}$ & $\begin{array}{c}2.79 \\
(1.04)\end{array}$ \\
\hline
\end{tabular}

Note: Means and deviations are at the teacher level and are associated with teachers in the sample. 
As mentioned above, our measures of organizational conditions, other than salaries, are based on teachers' self reports. Teachers' responses in any individual school, of course, may vary because teachers in the same building may perceive various conditions differently. In background analyses, we partitioned the variance of each measure of organizational conditions into within-school and between-school components. The intraclass correlation, or the portion of the variation that lies between schools, ranged from 13\% for subject-area professional development to $43 \%$ for student discipline, indicating that part of each measure is unique to each teacher respondent and that part is common to all teachers within a school. Elsewhere, we have explicitly compared the relative association with turnover of these two levels of measures of organization conditions (see Ingersoll \& May, 2010). Our focus here is on whether particular school-wide organizational conditions on average are related to minority and White turnover. Hence, for our measures of organizational conditions, we calculate averages across the entire sample of teachers in each school.

Our analysis used PROC GENMOD in SAS (version 9.2) because it adjusts for the nonrandom clustering of teachers within schools resulting from the multilevel structure of the sample and uses within- and between-school predictor variables to estimate separate effects across multiple levels. This procedure also supports logistic regression and allows for inclusion of sampling design weights. Weights are necessary because the SASS and TFS over- or undersample certain segments of the teaching population. Though the TFS data are longitudinal in the sense that the turnover outcomes transpired a year after the collection of the SASS measures of school characteristics and organizational conditions, it is important to note that any relationships found between these variables and turnover represent statistical associations between measures and do not imply causality. 


\section{Results}

\section{Trends in Minority Teacher Recruitment and Employment}

The data show that minority teachers continue to represent a small portion of the teaching force and that a gap persists between the percentage of minority students and the percentage of minority teachers in the U.S. school system. For instance, in the 2007-08 school year, 34\% of the nation's population was minority, $41 \%$ of all elementary and secondary students were minority, and only $16.5 \%$ of all elementary and secondary teachers were minority. But the data also show that this gap is not due to a failure to recruit minority teachers. Indeed, efforts to recruit minorities appear to have been highly successful.

After a period of decline during the 1970s, elementary and secondary student enrollments began to grow steadily in the U.S., beginning in the mid-1980s and continuing to the present. As Table 3 shows, over the two decades between 1988 and 2008, the elementary and secondary student population as a whole increased by $19 \%$. But this varied by the race/ethnicity of students. While the number of White students decreased by $2 \%$ during those two decades, the number of minority students increased by $73 \%$.

The teaching force, as a whole, also increased over this same two-decade period but, strikingly, by $48 \%$ — a rate over two times that of the overall growth rate for students of $19 \%$. Elsewhere we present a closer examination of the reasons behind this relatively dramatic growth in the teaching force (see, Ingersoll \& Merrill, 2010); our focus here is on increase of teachers by their race/ethnicity. While the number of White teachers increased by $41 \%$, the number of minority teachers increased by $96 \%$ (see Figure 2). 
Hence, in recent decades the rate of growth in the number of minority teachers has outpaced that of minority students and that of White teachers. As a result, in spite of the overall ballooning of the teaching force, the percentage of minority teachers has increased, from $12.4 \%$ to $16.5 \%$. Nevertheless, in spite of this increased diversity in the teaching force, the school system is no closer to demographic parity; that is, there remains a gap between the percentage of minority students and the percentage of minority teachers. This is largely due to a decline in the number of White students in recent decades.

There have also been some interesting differences in gender by race/ethnicity; the teaching force has become more female, but this differs by race/ethnicity. While the number of White female teachers increased by $51 \%$ during this period, the number of White male teachers increased by only $18 \%$. At the same, the number of minority female teachers increased by $97 \%$, and the number of minority male teachers increased by $92 \%$. In 2008, males represented about one quarter of both the White and minority portions of the teaching force.

The large increase in minority teachers has also not been evenly distributed across schools. The data show that less than one tenth of minority teachers work in private schools, while the majority of minority teachers are concentrated in public schools serving high-poverty, high-minority or urban communities.

To illustrate the public sector distribution for 2003-04, we subdivided the public teaching force into quartiles accordingly to the poverty and minority student enrollments of their schools. ${ }^{\text {iii }}$ 
Table 3. Trends in the Nation's Population, K-12 Student Enrollment, and the K-12 Teaching Force, by Race/Ethnicity

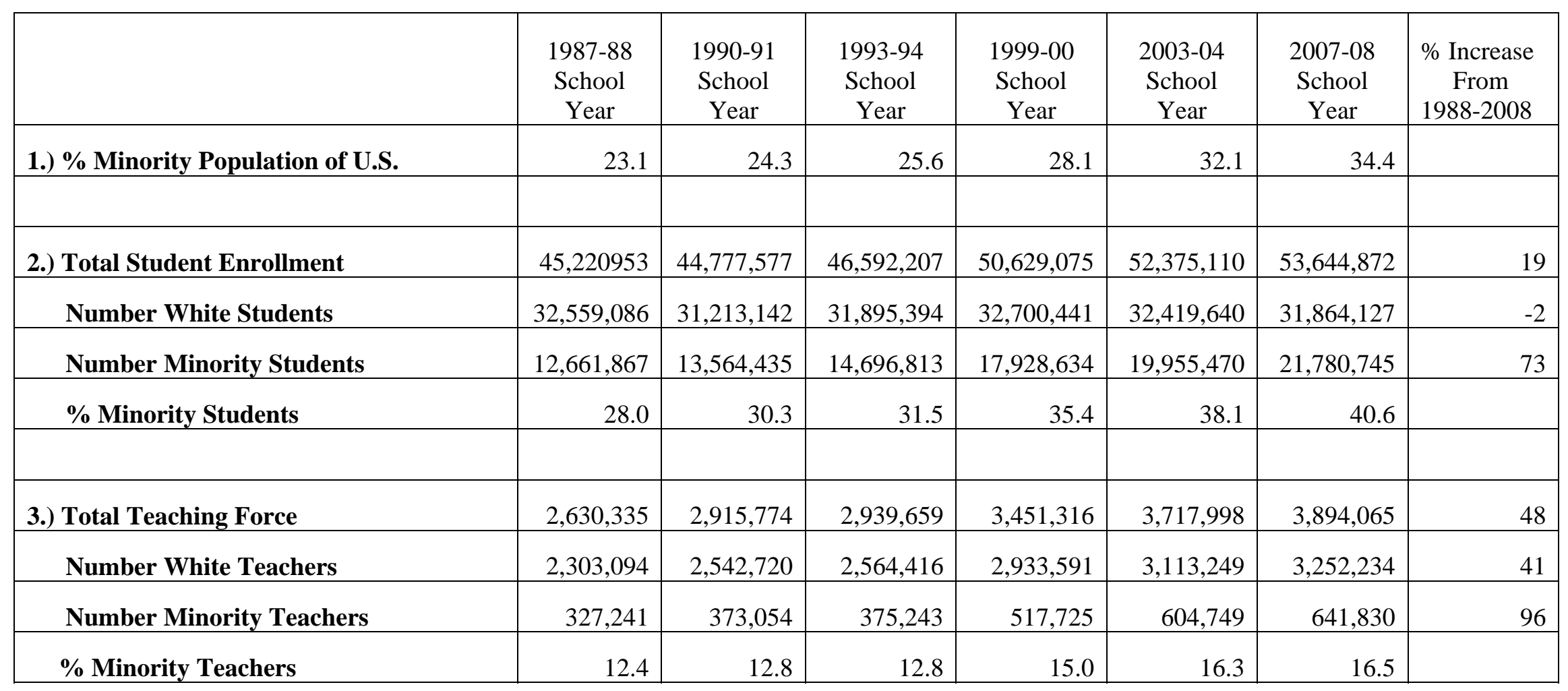


Figure 2. Percentage Increase in Students and Teachers, by Race/ethnicity from 1987-88 to 2007-08

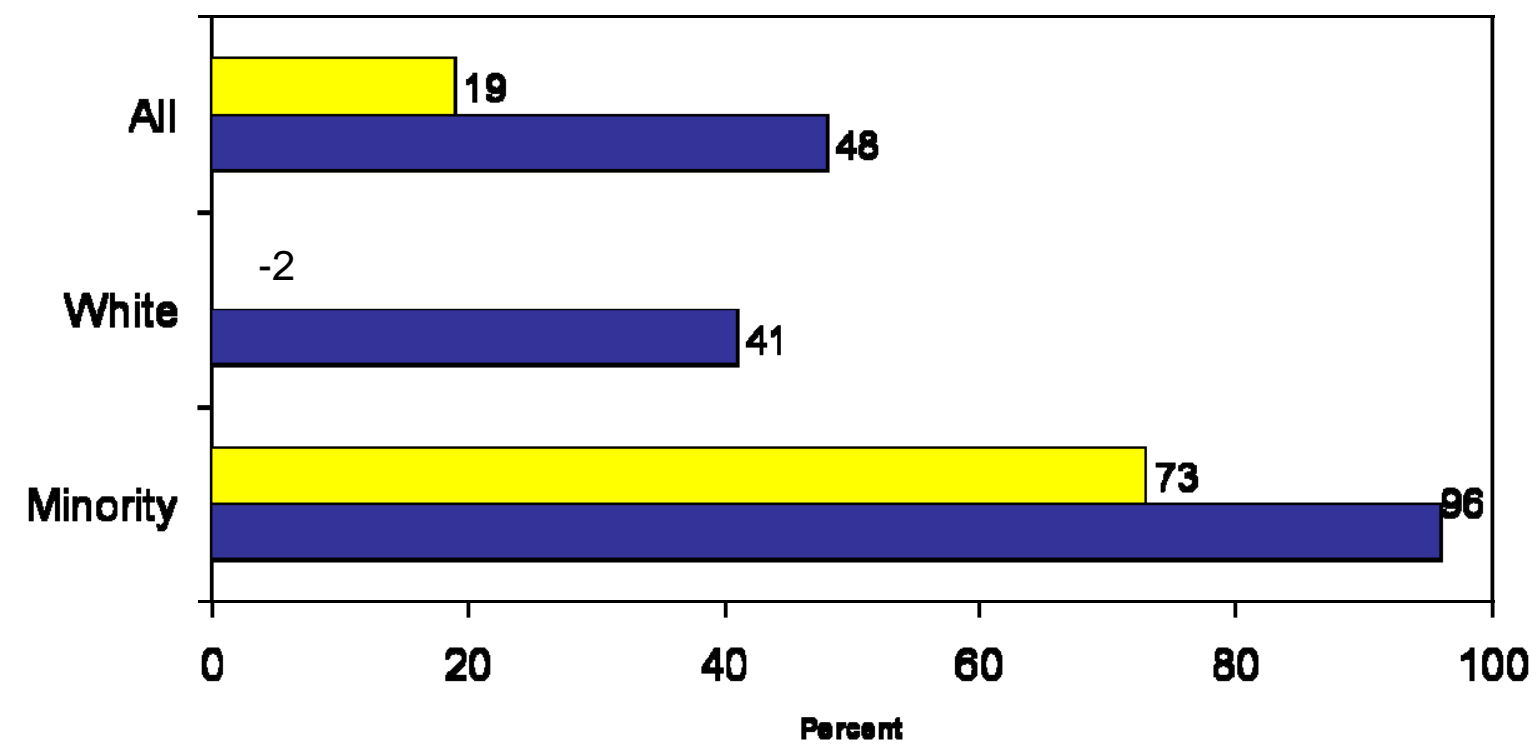

\section{$\square$ Students $\square$ Teachers}

As shown in Table 4, just over half of all public school minority teachers were employed in highpoverty schools, compared to only one fifth of White teachers. Similar patterns held for urban schools and high-minority schools. The opposite held for low-poverty, suburban and lowminority schools. For example, $11 \%$ of minority teachers taught in low-poverty schools, compared to $31 \%$ of White teachers.

Table 4. Of Minority and White Public School Teachers, Percentage Employed in Different Types of Schools, (2003-2004)

\begin{tabular}{lcc}
\hline School Demographic Characteristics & White & Minority \\
\hline Urban & 24 & 50 \\
Suburban & 55 & 39 \\
& & 53 \\
High Poverty & 20 & 11 \\
Low Poverty & 31 & 63 \\
High Minority & 18 & 4 \\
Low Minority & 31 & \\
\hline
\end{tabular}


It also important to note that, because minority teachers represented only $16.3 \%$ of the teaching force in 2003-04, in the same types of schools where minority teachers were disproportionately employed, the teaching staff overall was nevertheless predominantly White. Figure 3 illustrates this continuing lack of demographic parity. For instance, only $42 \%$ of teachers are minority in high-minority public schools (i.e., those with 75\% or more minority students). Likewise, only 35\% of teachers are minority in high-poverty public schools.

Figure 3. Of Different Types of Public Schools, Race/ethnicity of their Teaching Staff (2003-2004)

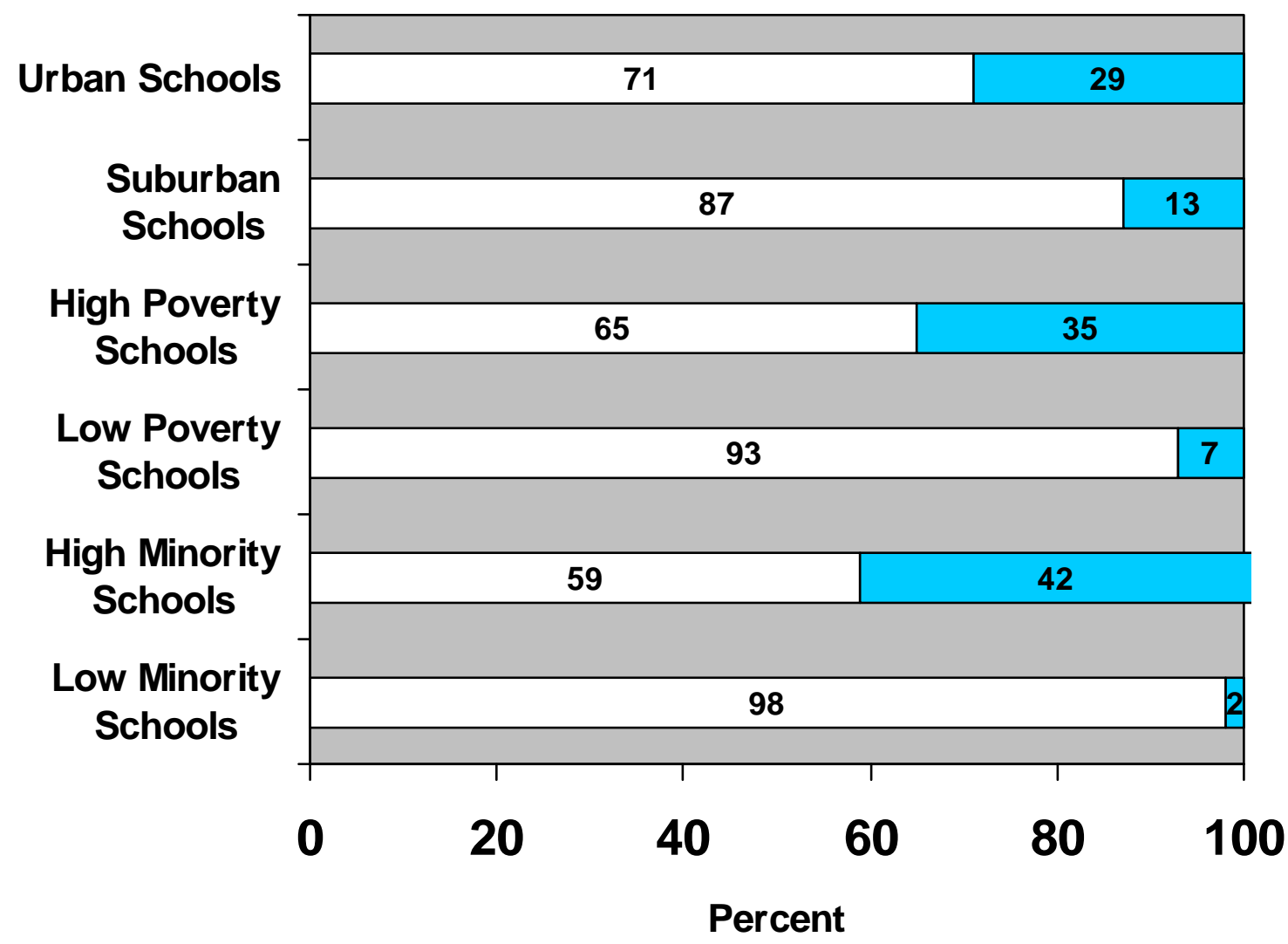


Table 5. Percentage Public School Teachers Reporting Less Positive Organizational Conditions, By Type of School (2003-04)

\begin{tabular}{|c|c|c|c|c|c|c|}
\hline & \multicolumn{6}{|c|}{ Type of School } \\
\hline & High Poverty & Low Poverty & $\begin{array}{c}\text { High } \\
\text { Minority }\end{array}$ & $\begin{array}{c}\text { Low } \\
\text { Minority }\end{array}$ & Urban & Suburban \\
\hline \multicolumn{7}{|l|}{$\begin{array}{c}\text { Organizational } \\
\text { Characteristics/Conditions }\end{array}$} \\
\hline Highest Salary $<\$ 70,000$ & 77 & 77 & 76 & 85 & 78 & 76 \\
\hline Serious Student Discipline Problems & 26 & 11 & 28 & 8 & 27 & 14 \\
\hline Inadequate Support from Leadership & 31 & 31 & 36 & 32 & 35 & 31 \\
\hline Inadequate School Resources & 28 & 17 & 31 & 14 & 28 & 19 \\
\hline Low Faculty Decision-making Influence & 49 & 39 & 49 & 39 & 48 & 42 \\
\hline Low Teacher Classroom Autonomy & 36 & 23 & 36 & 19 & 36 & 26 \\
\hline Not Useful Discipline-Focused Prof Dev & 54 & 64 & 57 & 63 & 39 & 41 \\
\hline Not Useful Content-Focused Prof. Dev. & 36 & 42 & 38 & 43 & 57 & 60 \\
\hline
\end{tabular}


The data also show that organizational characteristics and conditions in these same kinds of public schools differ. As Table 5 shows, teachers in high-poverty, high-minority, and urban schools were often more likely to report less positive school organizational conditions than those in low-poverty, low minority, and suburban schools. ${ }^{\text {iv }}$ For instance, $26 \%$ of teachers employed in high-poverty public schools reported the school having serious student discipline problems, compared to $11 \%$ of teachers in low-poverty schools. Similarly, $28 \%$ of teachers in urban public schools reported that textbooks and classroom supplies were inadequate, compared to $19 \%$ in suburban public schools. Likewise, 36\% of teachers employed in high-poverty public schools reported having very low levels of classroom autonomy, compared to $23 \%$ of teachers in lowpoverty schools. On the other hand, there were not large differences across poor and not poor schools in the maximum teacher salaries offered and in the case of useful professional development, teachers in low-poverty public schools reported a less positive situation.

\section{Trends in Minority Teacher Turnover}

In the two decades from the late 1980s to 2009, despite some fluctuations, the annual rate of overall teacher turnover (public and private) increased overall. This was especially true for minority teachers, whose turnover rate increased by $28 \%$ during this period. Moreover, during this period, the data also indicate that minority teachers tended to have higher rates of turnover than White teachers (Table 6). As illustrated in Figure 4, for four of the six cycles of the TFS data, total turnover rates for minorities were higher than those for White teachers, at a statistically significant level. In none of the cycles were minority turnover rates lower than those of White teachers at a statistically significant level. Moreover, this gap appears to have widened in the last decade. In the 2004-2005 and 2008-09 school years, minority turnover was, respectively, $18 \%$ and $24 \%$ higher than White teacher turnover. 
Table 6. Percentage Annual Teacher Migration and Attrition, by Race/ethnicity of Teachers, and by Year

\begin{tabular}{c|ccl|crl}
\hline \multicolumn{4}{c}{ Minority Teachers } & \multicolumn{3}{c}{ White Teachers } \\
\hline Year & Moves & Leaves & Total & Moves & Leaves & Total \\
\hline $1988-89$ & 9.2 & 5.9 & 15.1 & 7.9 & 6.5 & 14.4 \\
$1991-92$ & 7.0 & 6.1 & 13.1 & 7.2 & 6.0 & 13.2 \\
$1994-95$ & 9.2 & 7.6 & 16.8 & 6.7 & 7.2 & 13.9 \\
$2000-01$ & 8.4 & 7.5 & 15.9 & 7.7 & 8.2 & 15.9 \\
$2004-05$ & 9.0 & 10.4 & 19.4 & 7.6 & 8.8 & 16.4 \\
$2008-09$ & 10.1 & 9.2 & 19.3 & 6.7 & 8.9 & 15.6 \\
& & & & & & \\
\hline
\end{tabular}

Figure 4. Percent Annual Teacher Turnover, by Race/ethnicity of Teachers, by Year

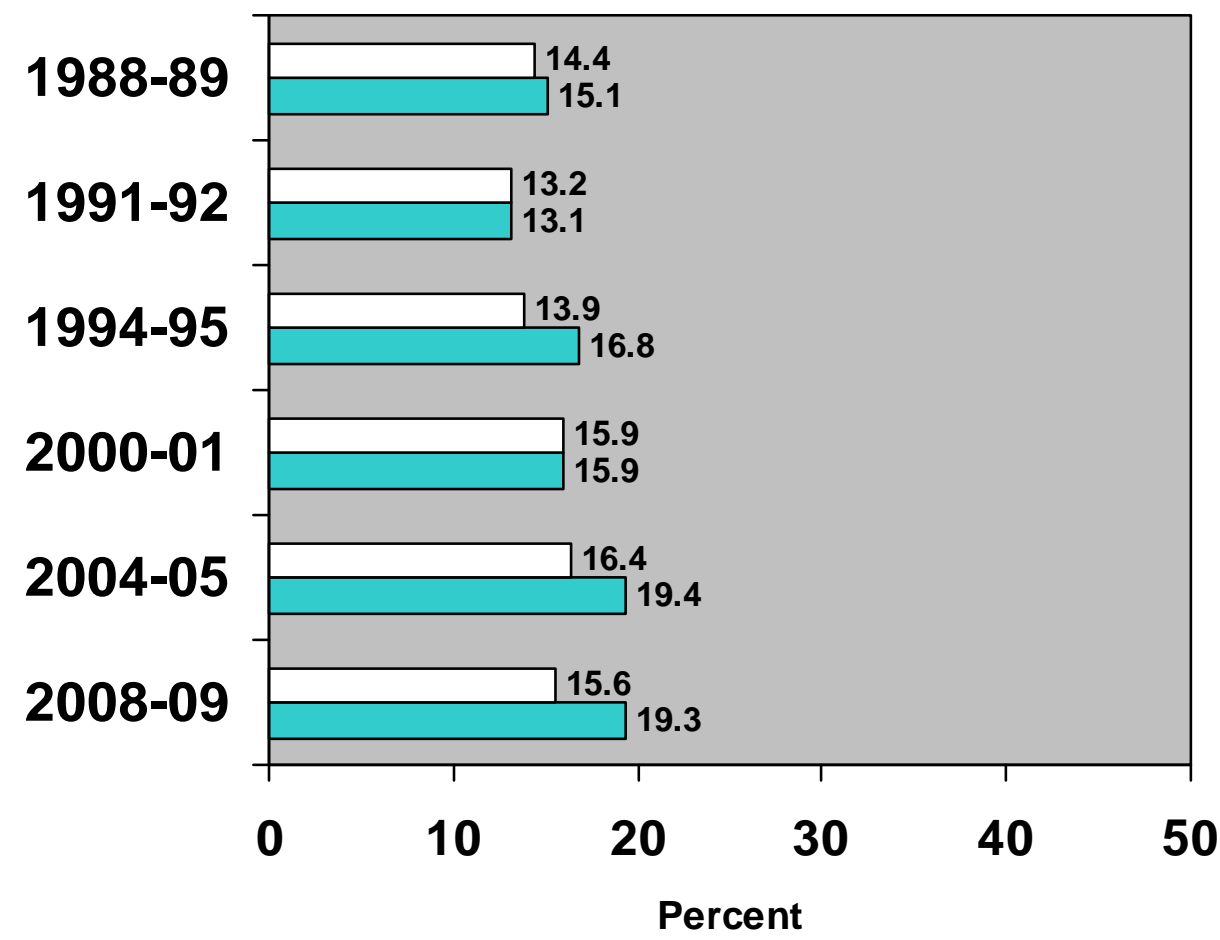

$\square$ White Teachers

Minority Teachers

Teacher turnover is not necessarily detrimental. In general, theory and research from the fields of organizational theory, economics and sociology have long held that some degree of employee turnover is normal and inevitable, and can be efficacious for individuals, for organizations, and for the economic system as a whole (e.g., Price, 1977, 1989; Jovanovic, 1979a, 1979b; Mobley, 1982; Abelson \& Baysinger, 1984; Hom \& Griffeth, 1995; Siebert \& 
Zubanov, 2009). Across a range of occupations and industries, job and career changing are normal and common, perhaps increasingly so, and some hold that high levels of employee turnover are a sign of economic opportunity and a dynamic, well-functioning economy (e.g., Kimmitt, 2007). Moreover, researchers have concluded that effective organizations usually promote some degree of employee turnover and benefit from it by the departure of low-caliber performers and the recruitment of "new blood" to facilitate innovation.

However, though there can be benefits to employee turnover, theory and research in these fields have also long held that employee turnover is not cost free. There is a general consensus that a variety of costs and consequences are associated with employee turnover, including the loss of human capital and of investments in employee development, the cost of replacement hiring and training, and disruption of production processes, and that such costs vary by industry and occupation.

Elsewhere we examine in detail the levels of turnover in teaching compared to other occupations and the benefits and costs of teacher turnover (see Ingersoll \& Perda, 2011). Here we focus on one consequence of the disproportionate loss of minority teachers—its implications for the minority teacher shortage. Figure 5 illustrates the significance of minority teacher attrition for minority teacher staffing using data from 2004-05 (the year with the highest annual level of minority attrition in our two-decade period). The data show that at the beginning of the 2003-04 school year, about 47,600 minority teachers entered the school system; however, by the following year, 20\% more—about 56,000—left teaching. ${ }^{\mathrm{v}}$ Interestingly, if minority teacher attrition in 2004-05 had been at a rate similar to that of White teachers that year (8.8\%), then the minority teacher outflow in Figure 5 would have been reduced to 47,521—about the same as the inflow earlier that year. 
Figure 5. Numbers of Minority Teachers Entering and Leaving Teaching Before and After the 2003-2004 School Year

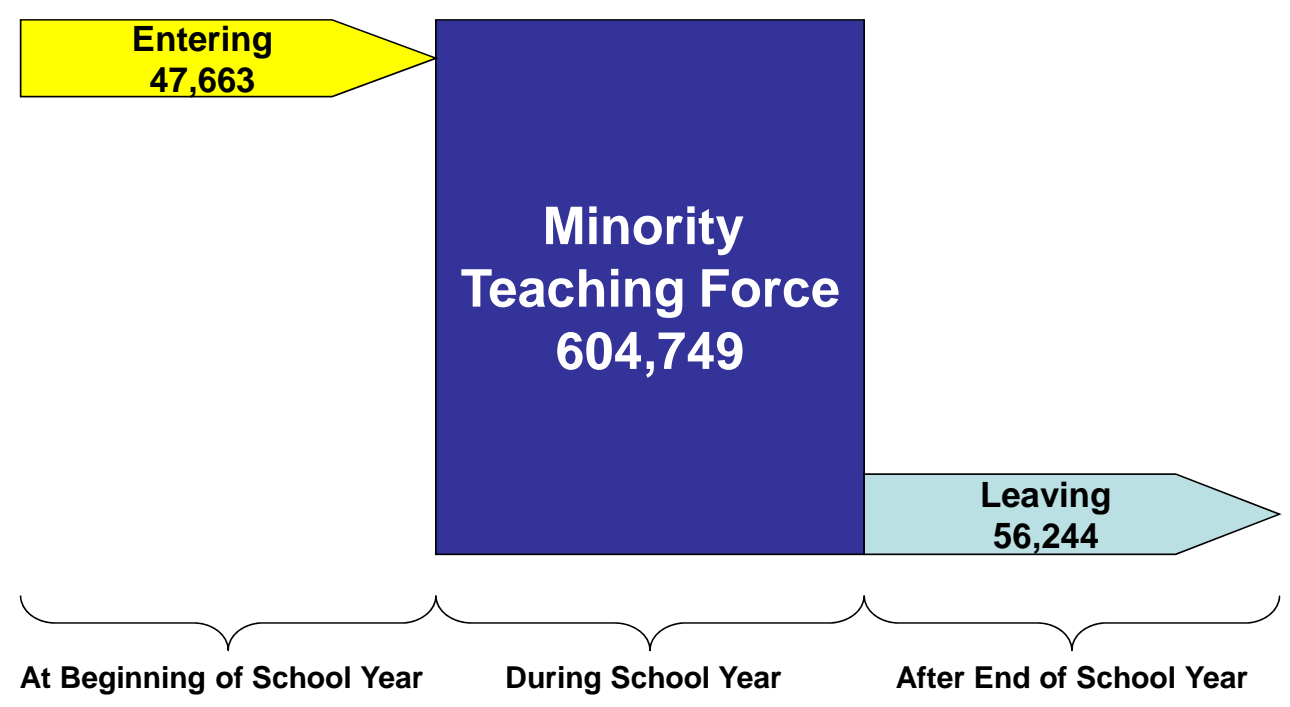

Some of those leaving teaching represent temporary attrition —-those who leave for a year or more and then return. Teachers who leave the occupation temporarily, of course, do not produce a permanent loss of human capital from the teacher supply and, hence, do not permanently contribute to overall shortages. In background analyses of the TFS data, we found that $51 \%$ of minority teachers and $61 \%$ of White teachers who left in 2004-05 reported that they would "consider returning to the position of K-12 teacher." Not all of those who consider returning do so. But significant numbers do return, and the re-entrance of former teachers is a major source of new supply. Indeed, 35\% of the 47,663 minority teachers in figure 5 who entered teaching in the beginning of the 2003-04 school year were former teachers re-entering the occupation. Our point here is that, regardless of whether we include temporary attrition in 
both the inflow and outflow in Figure 5, high levels of minority teacher attrition result in a need to continue-indeed, to increase-minority teacher recruitment to keep pace.

Teacher migration — those who transfer or move to different teaching jobs in other schools_-also has implications for minority teacher staffing problems. Migrants, of course, do not represent a net loss of human capital from the teacher supply and, hence, do not permanently contribute to overall systemic-level shortages. However, from an organizational-level perspective, employee migration can result in disproportionate gains and losses of human capital for particular kinds of schools.

Using the 2004-05 TFS data we were able to examine and compare the demographic characteristics of the original and destination schools of migrants who went from one public school to another. Interestingly, the data show that both minority and White teachers who moved between schools in that year were most likely to go to schools that were similar demographically to those from which they departed. For instance, in 2004-05, more than six times as many minority teachers moved from high-poverty schools to other high-poverty schools than moved from high-poverty schools to low-poverty schools. Similarly, almost three times as many minority teachers moved from urban schools to other urban schools than moved from urban to suburban schools. In the case of schools with different minority student populations, there was little migration at all across school types. For instance, while over 20,000 minority teachers moved from high-minority enrollment schools to other high-minority schools, only 550 minority teachers moved from high-minority to low-minority schools.

However, high-poverty schools, high-minority schools, and urban schools all have far higher rates of overall teacher migration than, respectively, low-poverty schools, low-minority schools, and suburban schools. Despite the fact that teachers tend not to move to 
demographically different schools, these higher overall rates from disadvantaged schools resulted in a net loss of minority teachers from high-poverty to low-poverty schools and from urban schools to suburban schools. For instance, of minority teachers who migrated between the 2004 and 2005 school years, almost twice as many moved from high-poverty schools to low-

poverty schools as the reverse. ${ }^{\mathrm{vi}}$ In sum, while minority teacher migration does not result in a net loss to the system, it does result in a large annual asymmetric loss of minority teachers from some of the same types of schools—urban and poor—in which minority teacher recruitment efforts have long sought to place minority candidates. These patterns provide further support for our theoretical perspective that fully understanding the minority teacher staffing problems of schools requires examining those problems from the perspective of the organizations in which they occur.

\section{The Determinants of Minority Teacher Turnover}

These data raise an important question: What are the reasons for and sources of these levels and patterns of White and minority teacher turnover? One way to answer this question is to examine self-report data from those who have moved or left. Tables 7 and 8 present data on the percentage of teachers in the TFS who reported that particular reasons were "very" or "extremely" important in their decisions to move or leave, on a five-point scale from "not important" to "extremely important." We grouped the individual reasons into categories as shown. Note that the percentages in the tables add up to more than $100 \%$, because respondents could indicate more than one reason for their departures. Again, we focus here on public schools, in which most minority teachers are employed.

As expected, retirement is a leading reason to leave teaching. Smaller portions of both movers and leavers indicated that their moves or leaves were a result of school staffing actions- 
such as their school being closed, or being laid off, transferred, reassigned or fired. Of those who left teaching, minority teachers were slightly less likely than White teachers to report they were laid off, terminated or reassigned.

Table 7. Of Public School Teachers Who Moved to Other Schools, Percentage Reporting Various Categories of Reasons Were Very or Extremely Important, by Race/ethnicity of Teachers, (2004-05)

White Minority

$\begin{array}{lcc}\text { School Staffing Action } & 18.5 & 19.3 \\ \text { Family or Personal } & 25.8 & 28.1 \\ \text { To Pursue Other Job } & 43.7 & 49.1 \\ \text { Dissatisfaction with Job } & 57.5 & 63.2\end{array}$

Note. In Table 7, we grouped 11 reasons for moving in the questionnaire into four categories, as follows:

(1) School Staffing Action: layoff/involuntary transfer

(2) Family or Personal: new school closer to home

(3) To Pursue Other Job: felt job security higher at another school; opportunity for better teaching assignment at new school (subject or grade level)

(4) Dissatisfaction with Job: for better salary or benefits; dissatisfied with workplace conditions; dissatisfied with support from administration; dissatisfied with job responsibilities; lack of autonomy; dissatisfied with opportunities for professional development; dissatisfied with old school for other reasons.

Table 8. Of Public School Teachers Who Left Teaching, Percentage Reporting Various Categories of Reasons Were Very or Extremely Important, by Race/ethnicity of Teachers (2004-05)

White 31.1 15.7 43 29.4 30.7
Minority

32.9

9.7

45.3

35.4

35.3

Dissatisfaction with Job

Note. In Table 8, we grouped 12 reasons for leaving in the questionnaire into five categories, as follows:

(1) Retirement

(2) School Staffing Action: reduction-in-force/layoff/school closing/reassignment

(3) Family or Personal: change in residence; pregnancy/child rearing; health; other family or personal reasons

(4) To Pursue Other Job: to pursue position other than that of k-12 teacher; to take courses to improve career opportunities within education sector; to take courses to improve career opportunities outside of education sector (5) Dissatisfaction with Job: for better salary or benefits; dissatisfied with teaching as career; dissatisfied with previous school or teaching assignment 
Relatively large and similar portions of White and minority teacher outflows, both moving and leaving, were highly influenced by personal and family factors—a spouse's job required a move, health issues, closer proximity to a school, a desire to raise a family. These types of job transitions are, no doubt, normal occurrences in any workplace, occupation, or industry.

The most prominent set of factors behind both moving and leaving, according to teachers, was a desire to obtain a different job or career, or dissatisfaction with some aspect of their teaching job. This was even more true for minority teachers. Fifty-eight percent of White teachers reported that dissatisfaction with some aspect of their school was behind their move to a teaching job elsewhere; this was true for $64 \%$ of minority teachers. While $33 \%$ of minority teachers who left teaching indicated retirement was a major reason, 35\% reported a major reason was dissatisfaction and 35\% said it was due to desire for a better job. Unlike the first three categories in Tables 7 and 8 (retirement, school staffing actions, and family/personal), the last two categories (pursuing a different career or dissatisfaction) are more likely to be a matter of choice—suggesting the importance of investigating the impact of job and organizational conditions on these choices. But, as discussed in the Data/Methods section, there are limitations to these self-report data. For instance, it is unclear what factors might be behind the large portions of both White and minority teachers who departed for better jobs or because of dissatisfaction.

We follow up below with a multivariate analysis examining a more specific set of school organizational characteristics and conditions in public schools, based on data from the full set of respondents in SASS, while controlling for other factors, such as teacher age, gender, school grade level, school size and the demographic characteristics of schools. 


\section{Individual, School and Organizational Predictors of Minority Teacher Turnover}

We estimated a series of regression models using the SASS/TFS data to examine whether our predictor variables were associated with teacher turnover. The predictor variables and associated regression estimates from each model are shown in Tables 9 and 10. To evaluate whether relationships between the predictors and turnover differed by the teachers' race/ethnicity, we separately estimated our models for minority teachers and for White teachers; these are displayed side by side in the tables.

In Table 9, we sequentially entered the sets of measures for teacher characteristics and school characteristics, then added the school demographic measures separately and, finally, included all the measures in a full model. In Table 10, we sequentially added each of the organizational condition variables to a basic model that included the set of teacher characteristics, the set of school characteristics, and the set of school demographic measures.

As shown in Model 1 of Table 9, our analyses found that the individual demographic characteristics of teachers were related to their likelihood of staying or departing at a statistically significant level, after controlling for other factors. But this differed by the race/ethnicity of the teacher. The age of teachers was a salient predictor of the likelihood of turnover, but only for White teachers. Both younger (less than 30) and older (greater than 50) White teachers were far more likely to depart than were middle-aged White teachers. For instance, the relative odds of young White teachers departing were more than two times higher than for middle-aged White teachers. In contrast, younger and older minority teachers did not depart at higher rates than other minority teachers (Model 1). Gender was also a factor, but only for minority teachers. The odds of male minority teachers departing were over 50\% higher than for female minority teachers; for Whites, there was little or no gender difference. 
Some school characteristics were also related to turnover, but again this differed by the race/ethnicity of the teacher. Minority teachers in smaller schools departed at higher rates; an enrollment difference of 100 students was associated with a $3 \%$ difference in the odds of minority teachers departing. For White teachers, the relationship with school size was very small and not statistically significant.

As shown in Models 2, 3, 4 and 5, schools in urban areas, schools with higher percentages of low-income students, schools with higher percentages of minority students, and schools with higher percentages of minority teachers each had higher White turnover. For instance, a 10 percentage point increase in the proportion of poverty-level students was associated with a $6 \%$ increase in the odds of White teachers departing.

In contrast, there was no consistent or statistically significant relationship between the likelihood of minority teachers departing and these demographic characteristics of schools (with the exception of lower minority turnover in rural compared to urban schools). In other words, after controlling for the background characteristics of teachers and schools, minority teachers, on average, did not depart at significantly different rates from schools with different poverty levels, with different minority student levels or with different proportions of minority faculty.

Model 6 includes all of these predictors simultaneously; it examines whether the effects of the different measures of school demographics were independent or redundant. Interestingly, after controlling for the other school demographic characteristics, the student poverty enrollment of schools was no longer significantly related to White teacher turnover; minority enrollment and minority faculty remain related, but with only borderline statistical significance. 
Table 9. Logistic Regression Analysis of the Likelihood of Public School Minority and White Teacher Turnover

\begin{tabular}{|c|c|c|c|c|c|c|c|c|c|c|c|c|}
\hline \multirow{4}{*}{$\begin{array}{l}\text { Teacher N } \\
\text { School N }\end{array}$} & \multicolumn{2}{|c|}{ Model 1} & \multicolumn{2}{|c|}{ Model 2} & \multicolumn{2}{|c|}{ Model 3} & \multicolumn{2}{|c|}{ Model 4} & \multicolumn{2}{|c|}{ Model 5} & \multicolumn{2}{|c|}{ Model 6} \\
\hline & Minority & White & Minority & White & Minority & White & Minority & White & Minority & White & Minority & White \\
\hline & 6,766 & 36,378 & 6,766 & 36,378 & 6,181 & 34,014 & 6,753 & 36,346 & 6,181 & 34,014 & 6,181 & 34,014 \\
\hline & 3,304 & 8,223 & 3,304 & 8,223 & 2,977 & 7,549 & 3,294 & 8,213 & 2,977 & 7,549 & 2,977 & 7,549 \\
\hline Intercept & $-1.70^{* * *}$ & $-2.10^{* * *}$ & $-1.68^{* * *}$ & $-1.94^{* * *}$ & $-1.69^{* * *}$ & $-2.11^{* * *}$ & $-1.72^{* * *}$ & $-2.10^{* * *}$ & $-1.80^{* * *}$ & $-2.08^{* * *}$ & $-1.77^{* * *}$ & $-2.09^{* * *}$ \\
\hline \multicolumn{13}{|l|}{ Teacher Characteristics } \\
\hline$\overline{\text { Younger }}$ & 0.08 & $0.84^{* * *}$ & 0.07 & $0.83^{* * *}$ & 0.05 & $0.84^{* * *}$ & 0.08 & $0.82^{* * *}$ & 0.05 & $0.84^{* * *}$ & 0.04 & $0.82^{* * *}$ \\
\hline Older & -0.08 & $0.34^{* * *}$ & -0.08 & $0.33^{* * *}$ & -0.06 & $0.34^{* * *}$ & -0.08 & $0.33^{* * *}$ & -0.06 & $0.33^{* * *}$ & -0.07 & $0.33^{* * *}$ \\
\hline Male & $0.41^{* *}$ & 0.10 & $0.41^{* *}$ & $0.10^{\sim}$ & $0.48^{* *}$ & 0.10 & $0.41^{* *}$ & $0.10^{\sim}$ & $0.49^{* *}$ & 0.10 & $0.48^{* *}$ & 0.10 \\
\hline \multicolumn{13}{|l|}{$\underline{\text { School Characteristics }}$} \\
\hline$\overline{\text { Secondary Level }}$ & 0.06 & -0.10 & 0.09 & -0.07 & 0.02 & -0.02 & 0.06 & -0.04 & 0.07 & -0.05 & 0.05 & 0.00 \\
\hline School Size (in 100s) & $-0.03^{* *}$ & 0.00 & $-0.04^{* *}$ & 0.00 & $-0.04^{* *}$ & 0.00 & $-0.03^{* *}$ & -0.01 & $-0.04^{* *}$ & -0.01 & $-0.04^{* *}$ & -0.01 \\
\hline \multicolumn{13}{|l|}{$\underline{\text { School Demographics }}$} \\
\hline$\overline{\text { Rural }}$ & & & $-0.33^{\sim}$ & $-0.26^{* * *}$ & & & & & & & -0.20 & -0.01 \\
\hline Suburban & & & 0.05 & $-0.20^{* *}$ & & & & & & & 0.11 & 0.03 \\
\hline Poverty Enrollment (in 10s) & & & & & -0.02 & $0.06^{* * *}$ & & & & & -0.03 & 0.01 \\
\hline Minority Enrollment (in 10s) & & & & & & & 0.01 & $0.05^{* * *}$ & & & -0.02 & $0.05^{* *}$ \\
\hline Minority Faculty (in 10s) & & & & & & & & & 0.02 & $0.11^{* * *}$ & 0.05 & $0.04^{\sim}$ \\
\hline
\end{tabular}

Note. $\stackrel{\sim}{\mathrm{p}}<.10, \stackrel{*}{\mathrm{p}}<.05, \stackrel{* *}{\mathrm{p}}<.01, \stackrel{* * *}{\mathrm{p}}<.001$ 
This suggests that the percentage of poverty-level students in schools is not independently related to White teachers' likelihood of departing, once the percentage of minority students in schools is held equal. On the other hand, this also suggests that the percentage of minority students in schools is significantly and independently related to White teacher turnover, even after holding school poverty levels constant. In contrast, for minority teachers, as in the other models, none of the demographic characteristics of schools was significantly related to turnover. After controlling for these demographic characteristics of teachers and schools, were the organizational conditions of schools associated with turnover? In each of the models shown in Table 10, the introduction of the organizational variable improved the model likelihood statistic by a statistically significant amount; moreover, after controlling for the characteristics of teachers and schools, most of the measured conditions were significantly associated with turnover. But, again, this depended on the race/ethnicity of the teacher.

The measure for top salaries (the highest annual salary in the school district's teacher salary scale) had a statistically significant negative bivariate relationship with turnover before controlling for school characteristics; not surprisingly, higher salaries were associated with lower turnover. However, once other background factors were held constant, as shown in Model 7, the coefficient for highest salaries was of only borderline statistical significance for White teachers. The coefficient for minority teachers was the same magnitude (-.06) as for White teachers, but was not statistically significant. The SASS data indicate that in 2003-04, the average starting salary in public schools for a teacher with a bachelor's degree and no experience was about $\$ 32,000$, and the average maximum salary (the measure used here) was about $\$ 61,000$.

As shown in Model 8, in schools with higher levels of student discipline problems, turnover rates were distinctly higher for White teachers; the relationship was in the same 
direction for minority teachers, but not at a statistically significant level. The former is one of the stronger relationships we found. A 1-unit increase in average reported student discipline problems between two schools (on a 5-unit scale) was associated with a $31 \%$ increase in the odds of a White teacher departing.

As shown in Model 9, in schools that provide better principal leadership and administrative support, as reported by teachers, turnover rates for both minority and White teachers were lower. However, again, the relationship with minority teacher turnover was not strong enough to reach a statistical significance. A one-unit difference between schools in average reported support (on a four-unit scale) was associated with a $22 \%$ decrease in the odds of a White teacher departing.

In schools where teachers reported that necessary materials were available, such as textbooks and supplies, turnover appeared lower for White teachers, but not at a level of statistical significance (Model 10). As shown in Model 11, schools with higher levels of schoolwide faculty decision-making influence had lower levels of turnover for both White and minority teachers. This is also one of the stronger relationships we found, and especially so for minority teachers. A one-unit increase in reported faculty influence between schools (on a four-unit scale) was associated with a $37 \%$ decrease in the odds of a minority teacher departing.

As shown in Model 12, schools with higher average levels of individual teachers’ classroom autonomy had lower levels of turnover-and, again, this was especially true for minority teachers. A one-unit difference in reported teacher influence between schools (on a four-unit scale) was associated with a $40 \%$ difference in the odds of a minority teacher departing. 
Table 10. Logistic Regression Analysis of the Likelihood of Public School Minority and White Teacher Turnover

\begin{tabular}{|c|c|c|c|c|c|c|c|c|c|c|c|c|}
\hline \multirow{4}{*}{$\begin{array}{l}\text { Teacher N } \\
\text { School N }\end{array}$} & \multicolumn{2}{|c|}{ Model 7} & \multicolumn{2}{|c|}{ Model 8} & \multicolumn{2}{|c|}{ Model 9} & \multicolumn{2}{|c|}{ Model 10} & \multicolumn{2}{|c|}{ Model 11} & \multicolumn{2}{|c|}{ Model 12} \\
\hline & Minority & White & Minority & White & Minority & White & Minority & White & Minority & White & Minority & White \\
\hline & 5,418 & 28,957 & 6,181 & 34,014 & 6,181 & 34,014 & 6,181 & 34,014 & 6,181 & 34,014 & 6,181 & 34,014 \\
\hline & 2,558 & 6,408 & 2,977 & 7,549 & 2,977 & 7,549 & 2,977 & 7,549 & 2,977 & 7,549 & 2,977 & 7,549 \\
\hline Intercept & $-1.99^{* * *}$ & $-2.07^{* * *}$ & $-1.76^{* * *}$ & $-2.07^{* * *}$ & $-1.77^{* * *}$ & $-2.08^{* * *}$ & $-1.77^{* * *}$ & $-2.09^{* * *}$ & $-1.79^{* * *}$ & $-2.09^{* * *}$ & $-1.88^{* * *}$ & $-2.15^{* * *}$ \\
\hline \multicolumn{13}{|l|}{ Teacher Characteristics } \\
\hline Younger & 0.10 & $0.88^{* * *}$ & 0.03 & $0.82^{* * *}$ & 0.03 & $0.82^{* * *}$ & 0.04 & $0.82^{* * *}$ & 0.03 & $0.82^{* * *}$ & 0.04 & $0.82^{* * *}$ \\
\hline Older & 0.05 & $0.36^{* * *}$ & -0.08 & $0.33^{* * *}$ & -0.07 & $0.33^{* * *}$ & -0.07 & $0.33^{* * *}$ & -0.10 & $0.32^{* * *}$ & -0.08 & $0.32^{* * *}$ \\
\hline Male & $0.50^{* *}$ & $0.12^{\sim}$ & $0.47^{* *}$ & 0.08 & $0.48^{* *}$ & 0.09 & $0.48^{* *}$ & 0.1 & $0.49^{* * *}$ & 0.10 & $0.49^{* * *}$ & $0.11^{\sim}$ \\
\hline \multicolumn{13}{|l|}{ School Characteristics } \\
\hline$\overline{\text { Secondary Level }}$ & 0.02 & -0.02 & 0.00 & -0.07 & 0.04 & -0.02 & 0.05 & -0.01 & 0.02 & 0.00 & 0.11 & 0.06 \\
\hline School Size (in 100s) & $-0.04^{*}$ & -0.01 & $-0.04^{* *}$ & $-0.01^{*}$ & $-0.04^{* *}$ & -0.01 & $-0.04^{* *}$ & -0.01 & $-0.04^{* *}$ & -0.01 & $-0.04^{* *}$ & $-0.01^{\sim}$ \\
\hline \multicolumn{13}{|l|}{ School Demographics } \\
\hline Rural & -0.09 & -0.07 & -0.17 & 0.02 & -0.18 & -0.02 & -0.21 & 0.00 & -0.16 & -0.01 & -0.08 & 0.05 \\
\hline Suburban & $0.29^{\sim}$ & 0.01 & 0.13 & 0.05 & 0.12 & 0.03 & 0.10 & 0.03 & 0.14 & 0.03 & 0.15 & 0.04 \\
\hline Poverty Enrollment (in 10s) & -0.02 & 0.00 & -0.03 & -0.01 & -0.03 & 0.01 & -0.03 & 0.01 & -0.03 & 0.01 & -0.04 & 0.01 \\
\hline Minority Enrollment (in 10s) & 0.00 & $0.06^{* *}$ & -0.02 & $0.05^{* *}$ & -0.02 & $0.05^{* *}$ & -0.01 & $0.05^{* *}$ & -0.02 & $0.05^{* *}$ & -0.02 & $0.05^{* *}$ \\
\hline Minority Faculty (in 10s) & 0.04 & 0.04 & 0.05 & $0.04^{\sim}$ & 0.05 & $0.04^{\sim}$ & 0.05 & $0.04^{\sim}$ & 0.05 & $0.04^{\sim}$ & 0.05 & $0.04^{\sim}$ \\
\hline \multicolumn{13}{|l|}{ Organizational Conditions } \\
\hline Highest Salary (in $\$ 10,000$ s) & -0.06 & $-0.06^{\sim}$ & & & & & & & & & & \\
\hline Student Discipline Problems & & & 0.13 & $0.27^{* * *}$ & & & & & & & & \\
\hline School Leadership Support & & & & & -0.11 & $-0.25^{* * *}$ & & & & & & \\
\hline School Resources & & & & & & & 0.06 & -0.10 & & & & \\
\hline Faculty Influence & & & & & & & & & $-0.47^{* *}$ & $-0.19^{*}$ & & \\
\hline Teacher Autonomy & & & & & & & & & & & $-0.51^{*}$ & $-0.38^{* * *}$ \\
\hline
\end{tabular}

Note. $\stackrel{\sim}{\mathrm{p}}<.10, \stackrel{*}{\mathrm{p}}<.05, \stackrel{* *}{\mathrm{p}}<.01, \stackrel{* * *}{\mathrm{p}}<.001$ 
We also examined the relationship to turnover of whether teachers participated in, and found useful, two types of professional development: 1) professional development focused on student discipline and classroom management, and 2) professional development focused on the content of the subjects taught. For both types of development, and for both White and minority teachers, the association with turnover was small and not statistically significant and, hence, we did not display these here.

The separate models in Table 10 estimate the independent relationships to turnover of each organizational condition. However, as discussed in the Data/Methods section, the above organizational conditions do not exist in isolation; schools with higher levels of one were also likely to have higher levels of others. To get a sense of the joint association with turnover of multiple organizational conditions we estimated predicted turnover rates by entering a range of values for the set of all organizational variables. Holding the control variables constant at the sample mean, we set the eight organizational condition variables to values corresponding to the $10^{\text {th }}$ percentile, the $25^{\text {th }}$ percentile, the mean, the $75^{\text {th }}$ percentile, and the $90^{\text {th }}$ percentile for the sample. This allowed us to predict the turnover rates of minority and White teachers for a range of hypothetical schools, beginning with those that have the worst organizational conditions (i.e., at the $10^{\text {th }}$ percentile on each of the eight organizational measures) and concluding with those that have the best organizational conditions (i.e., at the $90^{\text {th }}$ percentile on each of organizational measures). Results from this analysis are depicted in Figure 6 and reveal a clear collective relationship between organizational conditions and turnover. This relationship is remarkably strong for minority teachers, whose predicted annual turnover rates are only $12 \%$ in the schools with the best organizational conditions versus nearly $21 \%$ in schools with the worst 
organizational conditions. For White teachers the relationship is not as strong, ranging from $12 \%$ in the best schools to $15 \%$ in the worst schools. ${ }^{\text {vii }}$

Moreover, we estimated our sequential sets of models in Tables 9 and 10 on several permutations of our teacher data file. First, we tested our models using a comprehensive data file combining both White and minority teachers, while adding a predictor for minority teachers (table not displayed here). Consistent with our descriptive statistics in Table 6, minority teachers had a statistically significantly higher likelihood of turnover than did White teachers. The odds of minority teachers departing were almost $50 \%$ higher than for White teachers, even after controlling for the characteristics of teachers and schools. However, once organizational conditions were controlled, the coefficient for minority teachers became statistically insignificant and small (the odds of minority teachers departing were less than 5\% higher than for White teachers). In other words, we found that less positive organizational conditions in schools accounted for the higher rates of minority teacher turnover.

We also estimated our same set of models separately for movers and leavers to explore differences in the predictors of each component of turnover (table not displayed here). This analysis necessarily used the smaller TFS sample. Given the smaller sample, as expected, some of the coefficients for organizational conditions failed to achieve statistical significance. However, in almost all cases, the direction and magnitude of the coefficients for organizational conditions were similar to those found in the models analyzing the full sample in Tables 9 and10. In other words, organizational conditions associated with differences in rates of teacher migration were similarly associated with differences in rates of teacher attrition. 


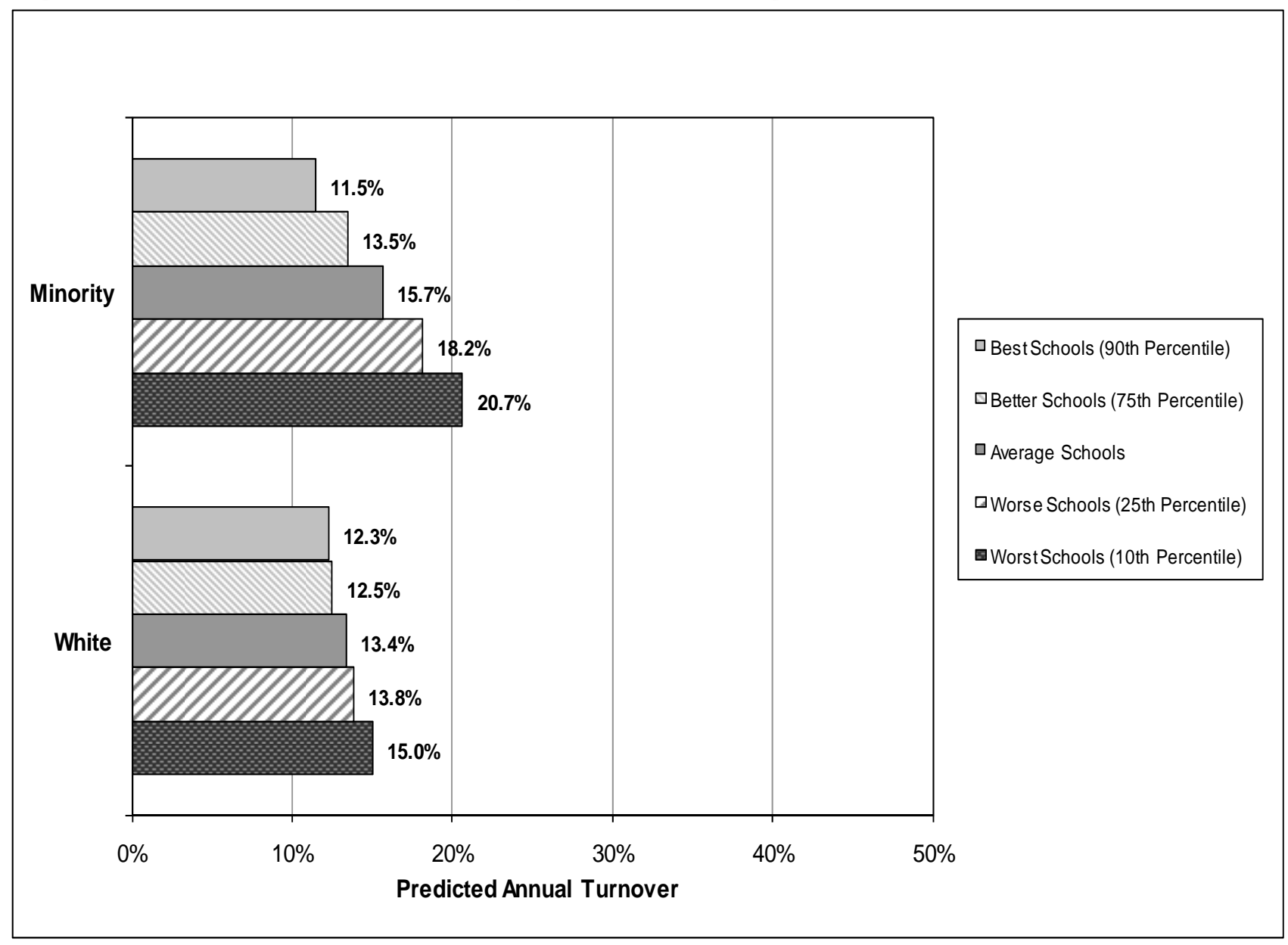

There were, however, some interesting differences in the relationship of school demographic characteristics to these types of departures. For White teachers, school demographic characteristics, especially minority student enrollment, had a stronger relationship to moving than to leaving. After controlling for our other variables, schools with higher percentages of low-income students, higher percentages of minority students, and higher percentages of minority teachers had higher White teacher migration to other schools; for Whites leaving teaching altogether, the differences were small and not statistically significant.

In contrast, for minority teachers, there continued to be little relationship between school demographic characteristics and the likelihood that minority teachers would either move between 
schools or leave teaching, with one interesting exception: there was a small but statistically significant negative relationship between poverty enrollment and minority teacher migration. Minority teachers in schools with higher poverty-level enrollments were slightly less likely to migrate to other schools, than those in lower-poverty schools.

Finally, we estimated our same set of models on a subset of turnover that excluded those who departed because of retirement, layoffs, terminations or school closings, in order to test our findings using a file approximating only voluntary departures. When looking at departures that are, ostensibly, a matter of choice, we would expect organizational conditions to have a clearer and stronger relationship to turnover. On the other hand, to do this analysis, it was necessary to use the smaller TFS sample; given the smaller sample, we would expect some variables to have a weaker relationship. We found that the magnitude of the association of many of our predictors increased and that the findings were highly consistent with those in the models in Tables 9 and 10.

\section{Summary and Implications}

It is widely believed that the nation's schools suffer from dire shortages of minority teachers. Numerous scholars and commentators have held that there is a growing mismatch between the degree of racial/ethnic diversity in the nation's student population and the degree of diversity in the nation's elementary and secondary teaching force. In response, in recent decades numerous government and non-government organizations have implemented a variety of minority teacher recruitment programs and initiatives. Have these efforts been successful? Has the teaching force grown more diverse?

The national data show a gap persists between the percentage of minority students and the percentage of minority teachers in the U.S. school system. For instance in 2008, $34 \%$ of the 
nation's population was minority, and $41 \%$ of all elementary and secondary students were minority, but only $16.5 \%$ of all elementary and secondary teachers were minority. But the data also show this gap is not due to a failure of teacher recruitment. Indeed, since the late 1980s the number of minority elementary and secondary teachers has ballooned by almost $100 \%$, outpacing growth in the number of White teachers and outpacing growth in minority students. The result is that the teaching force has rapidly grown more diverse.

Moreover, minority teachers are overwhelmingly employed in public schools serving high-poverty, high-minority, and urban communities. Minority teachers are two to three times more likely than White teachers to work in such hard-to-staff schools. Hence, the data show that, in spite of a purported host of barriers to entry and competition from other occupations for minority college graduates, efforts over recent decades to recruit more minority teachers and place them in schools serving disadvantaged and minority student populations have been very successful.

However, overall, the data show that over the past two decades minority teachers were also less stable than White teachers; in most years they were more likely to migrate from one school to another or to leave teaching altogether. This was especially true for male minority teachers. The result has been that, numerically, there has been a large degree of job transition among minority teachers each year. For instance, during the 12 months from the beginning of the 2003-04 school year to the following year, about one third of the approximately 600,000 minority teachers in the nation moved into, between, or out of schools.

Some turnover of teachers is, of course, normal, inevitable, and beneficial. For individuals, departures leading to better jobs, either in teaching or not, can be a source of upward mobility. For schools, departures of low-performing employees can enhance organizational 
outcomes. For the educational system, some teacher outflows, such as cross-school migration, temporary attrition, or those leaving classroom teaching for other education-related jobs, do not represent a net or permanent loss of human capital to the education system as a whole.

However, from an organizational level of analysis and from the viewpoint of those managing schools, none of these types of departures are cost free, whether permanent, to other schools, or to other education jobs. All have the same effect; they typically result in a decrease in minority classroom instructional staff in that organization. One consequence of such turnover, our analysis reveals, is that it undermines efforts to address the minority teacher shortage.

Why do minority teachers depart schools at higher rates? Strikingly, while the demographic characteristics of schools appear to be highly important to minority teachers' initial employment decisions, this does not appear to be the case for their later decisions about whether to depart. A school's enrollment of poverty-level students, a school's minority-student enrollment, the school's proportion of minority teachers, or whether the school lies in an urban or suburban community were not strongly or consistently related to the likelihood that minority teachers would decide to stay or depart. On the other hand, our data also show that after controlling for other factors, school demographics were significantly related to White teachers' turnover decisions. Hence, like other studies (see, e.g., Achinstein, et al. 2010), we found that, compared to White teachers, minority teachers were less likely to turnover from high-poverty, and high minority, and urban schools. But this was not due to any kind of minority teacher affinity for, or commitment to, employment in such schools, as is widely believed (e.g., Irvine 1988). When it comes to the turnover of minority teachers, the demographic characteristics of the students appear to be non factors. This also appears to be true for the largest subgroup within the minority teaching force-Black and African American teachers. In a companion study, 
Connor (2011) focused specifically on Black and African American teachers, comparing them to White teachers. His findings on turnover were similar to those reported in our study.

Among the most prominent reasons teachers gave for leaving or moving were a desire to obtain a better job or career, or dissatisfaction with some aspect of their teaching job. And not only did minority teachers depart at higher rates, but among those who moved or left, minority teachers were more likely to cite career advancement or job dissatisfaction than were White teachers.

The data further show that particular school organizational conditions were strongly related to these minority teacher departures. Hard-to-staff schools that are more likely to employ minority teachers often also have less desirable organizational conditions. And less desirable conditions, our data suggest, account for the higher rates of minority teacher turnover. In other words, the data indicate that minority teachers departed at higher rates because the schools in which they were employed tended to have less positive organizational conditions. The strongest organizational factors for minority teachers were the levels of collective faculty decision-making influence in their school and the degree of individual instructional autonomy held by teachers in their classrooms. Schools that provided more teacher classroom discretion and autonomy, as well as schools with higher levels of faculty input into school decision-making influence, had lower levels of minority teacher turnover. Other factors, such as salaries, the provision of professional development or the availability of classroom resources, had much less effect on turnover rates.

What are the implications of these results for the widespread efforts to diversify the teaching force? In supply and demand theory, any imbalance between labor demand and supply can be referred to as a shortage, in the sense that there is an inadequate quantity of individuals able and willing to offer their services under given wages and conditions. From this perspective, 
the problems many schools encounter retaining minority teachers can technically be referred to as a shortage. However, in the context of minority teachers and schools, the term shortage is typically given a narrower connotation—an insufficient production and recruitment of new minority teaching candidates in the face of increasing minority student enrollments. These terminological and diagnostic differences have crucial implications for prescription and policy.

As noted in the beginning of this article, increased teacher production and recruitment has long been the dominant strategy to diversify the teaching force and address the minority teacher shortage. Numerous high-profile reports have called for dramatic increases in the recruitment of new minority teachers across the nation (e.g., Education Commission of the States, 2003; American Association of Colleges of Teacher Education, 1987; National Educational Association, 2004). Beginning in the late 1980s, such efforts received substantial support and funding — the Ford Foundation and the DeWitt Wallace Readers' Digest Fund alone committed over $\$ 60$ million.

Nothing in our research suggests that bringing new qualified minority candidates into teaching is not a worthwhile step. Indeed, our data show that this approach has had remarkable success. In the two decades since the late 1980s, the minority teaching force has increased at over two and a half times the rate of the White teaching force—by 300,000—almost doubling in size.

But the data indicate that new teacher recruitment strategies alone do not directly address a major source of minority teacher staffing problems-turnover. This is especially true for minority teacher recruitment efforts aimed at male teachers, because male minority teachers have especially high turnover. Indeed, the ballooning of the minority teaching force is all the more remarkable because it has occurred in spite of the high turnover rate among minority teachers. 
To illustrate, our data reveal that at the beginning of the 2003-04 school year abut 48,000 minorities entered teaching. After the end of the school year, over 56,000 minority teachers left teaching. Of these, about 16,000 retired, another 30,000 indicated that they left to pursue another job or because of job dissatisfaction. Improving the retention of minority teachers brought into teaching by recruitment initiatives could prevent the loss of the investment, and also help to lessen the need for more recruitment initiatives. All of this suggests the efficacy of developing teacher recruitment and retention initiatives together.

These findings also have implications for the implementation of educational accountability reforms, which have increased since the enactment of NCLB in 2001. In preliminary analyses, we have found that in many states and school districts, the implementation of school and teacher accountability initiatives has been accompanied by decreases in levels of individual teacher classroom autonomy, especially in regard to the selection of texts, content, topics and evaluating of students in their courses - one of the organizational conditions strongly associated with minority teacher turnover (Ingersoll, 2007; also see Guggino \& Brint, 2010). Hence, depending on how they are implemented, accountability reforms may have the unintended and unfortunate consequence of increasing minority teacher turnover and minority teacher staffing problems. These issues are worthy of further investigation—a project we are now undertaking.

This study’s findings support the view that school organization, management, and leadership matter, and they shift attention to discovering which policy-amenable aspects of schools as organizations — their practices, policies, characteristics, and conditions—are related to their ability to retain minority teachers. The data suggest that poor, high-minority, urban schools with improved organizational conditions will be far more able to do so. To be sure, the data do not suggest that altering any of the organizational conditions we examined would be easy. 
However, unlike reforms such as teacher salary increases, professional development and classsize reduction, changing some conditions, such as teachers' classroom autonomy and faculty's school-wide influence, would appear to be less costly financially—an important consideration, especially in low-income settings and in periods of budgetary constraint. 


\section{References}

Abelson, M.A., \& Baysinger, B.D. (1984). Optimal and dysfunctional turnover: Toward an organizational level model. The Academy of Management Review, 9(2), 331-341.

Achinstein, B., \& Aguirre, J. (2008). Cultural match or cultural suspect: How new teachers of color negotiate socio-cultural challenges in the classroom. Teachers College Record, 110(8), 1505-1540.

Achinstein, B., Ogawa, R.T., Sexton, D., \& Freitas, C. (2010). Retaining teachers of color: A pressing problem and a strategy for "hard-to-staff” schools. Review of Educational Research, 80(1), 71-107.

American Association of Colleges of Teacher Education. (1999). Teacher education pipeline IV: Schools and departments of education enrollments by race, ethnicity, and gender. Washington, DC: Author.

Banks, J. (1995). Multicultural education: Historical development, dimensions, and practice. In J. Banks \& C. Banks (Eds.), Handbook of research on multicultural education (pp. 324). New York, NY: Macmillan.

Baron, J., \& Bielby, W. (1980). Bringing the firm back in: Stratification, segmentation, and the organization of work. American Sociological Review, 45, 737-765.

Bryk, A., Lee, V., \& Holland, P. (1993). Catholic schools and the common good. Cambridge, MA: Harvard University Press.

Carnegie Forum on Education and the Economy, Task Force on Teaching as a Profession. (1986). A nation prepared: Teachers for the 21st century. Washington, DC: Author.

Chandler, K., Luekens, M., Lyter, D., \& Fox, E. (2004). Teacher attrition and mobility: Results from the teacher follow-up survey, 2000-01. Washington, DC: National Center for Education Statistics.

Chubb, J.E., \& Moe, T. (1990). Politics, markets and America’s schools. Washington, DC: Brookings Institute.

Clewell, B.C., \& Villegas, A.M. (2001). Evaluation of the DeWitt Wallace-Reader's Digest Fund's Pathways to Teaching Careers program. Washington, DC: Urban Institute.

Cochran-Smith, M. (2004). Walking the road: Race, diversity, and social justice in teacher education. New York, NY: Teachers College Press.

Cole, B.P. (1986). The Black educator: An endangered species. Journal of Negro Education, 55(3), 326-334. 
Coleman, J., \& Hoffer, T. (1987). Public and private schools: The impact of communities. New York, NY: Basic.

Connor, R. (2011). Examining African American teacher turnover, past \& present. Unpublished $\mathrm{PhD}$ Dissertation, University of Pennsylvania.

Dilworth, M. (1992). Diversity in teacher education. San Francisco, CA: Jossey-Bass.

Dreeben, R., \& Gamoran, A. (1986). Race, instruction and learning. American Sociological Review, 51, 660-669.

Education Commission of the States. (2003). Recruiting teachers of color: A 50-state survey of state policies. Denver, CO: Author.

Feistritzer, E. (1997). Alternative teacher certification: A state-by-state analysis (1997). Washington, DC: National Center for Education Information.

Foster, M. (1994). Effective Black teachers: A literature review. In E. R. Hollins, J. E. King, \& W. C. Hayman (Eds.), Teaching diverse populations: Formulating a knowledge base (pp. 225-241). Albany, NY: State University of New York Press.

Foster, M. (1997). Black teachers on teaching. New York, NY: New Press.

Gandara, P. \& Maxwell-Jolley, J. (2000). Preparing teachers for diversity: A dilemma of quality and quantity. Santa Cruz, CA: The Center for the Future of Teaching \& Learning.

Goodlad, J. (1984). A place called school: Prospects for the future. St. Louis, MO: McGrawHill.

Grant, G. (1988). The world we created at Hamilton High. Cambridge, MA: Harvard University Press.

Guggino, P., \& Brint, S. (2010). Does the No Child Left Behind Act help or hinder K-12 education? Policy Matters, 3(3), 1-7.

Haberman, M. (1996). Selecting and preparing culturally competent teachers for urban schools. In J. Sikula (Ed.), Handbook of research on teacher education (pp. 747-760). New York, NY: Simon \& Schuster Macmillan.

Haycock, K. (2001). Closing the achievement gap. Educational Leadership, 58(6), 6-11.

Hirsch, P., \& Lounsbury, M. (1997). Putting the organization back into organization theory. Journal of Management Inquiry, 6, 79-88. 
Hirsch, E., Koppich, J., \& Knapp, M. (2001). Revisiting what states are doing to improve the quality of teaching: An update on patterns and trends. Seattle, WA: Center for the Study of Teaching and Policy, University of Washington.

Hom, P., \& Griffeth, R. (1995). Employee turnover. Cincinnati, OH: South-Western.

Ingersoll, R. (2001). Teacher turnover and teacher shortages: An organizational analysis. American Educational Research Journal, 38(3), 499-534.

Ingersoll, R. (2007). Short on power, long on responsibility. Educational Leadership, 65(1), 2025.

Ingersoll, R., \& May, H. (2010). The magnitude, destinations and determinants of mathematics and science teacher turnover. Philadelphia, PA: Consortium for Policy Research in Education, University of Pennsylvania.

Ingersoll, R., \& Merrill, E. (2010) Who's teaching our children? Educational Leadership, 67, 1420.

Ingersoll, R., \& Perda, D. (2011). How high is teacher turnover and is it a problem? Philadelphia, PA: Consortium for Policy Research in Education, University of Pennsylvania.

Irvine, J.J. (1988). An analysis of the problem of the disappearing Black educator. Elementary School Journal, 88(5), 503-514.

Irvine, J.J. (1989). Beyond role models: An examination of cultural influences on the pedagogical perspectives of Black teachers. Peabody Journal of Education, 66(4), 51-63.

Jovanovic, B. (1979a). Job matching and the theory of turnover. Journal of Political Economy, 87(5), 972-990.

Jovanovic, B. (1979b). Firm-specific capital and turnover. Journal of Political Economy, 87(6), 1246-1260.

Kalleberg, A. (1989). Linking macro and micro levels: Bringing the workers back into the sociology of work. Social Forces, 67, 582-592.

Kimmitt. R. (2007, Jan.23). Why job churn is good. Washington Post (p. A17).

Kirby, S.N., Berends, M., \& Naftel, S. (1999). Supply and demand of minority teachers in Texas: Problems and prospects. Educational Evaluation and Policy Analysis, 21(1), 47-66.

Ladson-Billings, G. (1995). Toward a theory of culturally relevant pedagogy. American Educational Research Journal, 32(3), 465-491. 
Lau, K.F., Dandy, E.B., \& Hoffman, L. (2007). The Pathways Program: A model for increasing the numbers of teachers of color. Teacher Education Quarterly, 34(4), 27-40.

Lewis, C.W. (2006). African American male teachers in public schools: An examination of three urban school districts. Teachers College Record, 108(2), 224-245.

Liu, E., Rosenstein, J., Swann, A., \& Khalil, D. (2008). When districts encounter teacher shortages: The challenges of recruiting and retaining math teachers in urban districts. Leadership and Policy in Schools, 7(3), 296-323.

Mobley, W. (1982). Employee turnover: Causes, consequences and control. Reading, MA: Addison-Wesley.

Murnane, R., Singer, J., Willet, J., Kemple, J., \& Olsen, R. (Eds.). (1991). Who will teach? Policies that matter. Cambridge, MA: Harvard University Press.

National Center for Education Statistics. (2005). Schools and staffing survey (SASS) and teacher follow-up survey (TFS). Data File. Washington, DC: U.S. Department of Education. Available from http://nces.ed.gov/surveys/SASS

National Collaborative on Diversity in the Teaching Force. (2004). Assessment of diversity in America's teaching force: A call to action. Washington, DC: National Educational Association.

Norton, R. (2005, April). Call me MISTER. Black Collegian, 27-28.

Oakes, J. (1985). Keeping track: How schools structure inequality. New Haven, CT: Yale University Press.

Oakes, J. (1990). Multiplying inequalities: The effects of race, social class, and tracking on opportunities to learn mathematics and science. Santa Monica, CA: The RAND Corporation.

Price, J. (1977). The study of turnover. Ames, IA: Iowa State University Press.

Price, J. 1989. The impact of turnover on the organization. Work and Occupations, 16, 461-473.

Quiocho, A. \& Rios, F. (2000). The power of their presence: Minority group teachers and schooling. Review of Educational Research, 70(4), 485-528.

Rice, J., Roellke, C., Sparks, D., \& Kolbe, T. (2008). Piecing together the teacher policy landscape: A policy-problem typology. Teachers College Record. Available from http://www.tcrecord.org/Content.asp?ContentId=15223

Rosenbaum, J. (1976). Making inequality. New York, NY: John Wiley \& Sons. 
Shen, J. (1998). Alternative certification, minority teachers, and urban education. Education and Urban Society, 31(1), 30-41.

Siebert, S.W., \& Zubanov, N. (2009). Searching for the optimal level of employee turnover: A study of a large U.K. retail organization. Academy of Management Journal, 52(2), 294-313.

Stolzenberg, R. (1978). Bringing the firm back in: Employer size, employee schooling and socioeconomic achievement. American Sociological Review, 43, 813-28.

Torres, J., Santos, J., Peck, N. L., \& Cortes, L. (2004). Minority teacher recruitment, development, and retention. Providence, RI: Brown University, Educational Alliance.

Valencia, R.R. (2002). The plight of Chicano students: An overview of schooling conditions and outcomes. In R.R. Valencia (Ed.), Chicano school failure and success, second edition (pp. 3-51). New York, NY: Routledge-Falmer.

Villegas, A.M. \& Lucas, T. (2004). Diversifying the teacher workforce: A retrospective and prospective analysis. In M.A. Smylie \& D. Miretky (Eds.), Developing the teacher workforce (103rd Yearbook of the National Society for the Study of Education, Part 1) (pp. 70-104). Chicago, IL: University of Chicago Press.

Villegas, A.M., \& Irvine, J.J. (2010, April). Diversifying the teaching force: An examination of major arguments. Urban Review, 42:175-192.

Wilson, W.J. (1996). When work disappears: The world of the new urban poor. New York, NY: Knopf.

Zeichner, K. (1996) Educating teachers for cultural diversity. In K. Zeichner, S. Melnick \& M.L. Gomez (Eds.), Currents of reform in preservice teacher education (pp. 133-175). New York, NY: Teachers College Press.

Zeichner, K. \& Gore, J. (1990). Teacher socialization. In W.R. Houston, M. Haberman \& J. Sikula (Eds.), Handbook of research on teacher education (pp. 329-348). New York, NY: Macmillan.

Zumwalt, K., \& Craig, E. (2005). Teachers' characteristics: Research on the demographic profile. In M. Cochran-Smith \& K.M. Zeichner (Eds.), Studying teacher education: The report of the AERA panel on research and teacher education (pp. 111-156). Mahwah, NJ: Lawrence Erlbaum. 


\section{Endnotes}

i The preliminary Teacher Status variable, from SASS, has some error in distinguishing between migration (movers) and attrition (leavers). Essentially, school principals tend to overreport the number of leavers because teachers who quit their jobs often do not inform their previous schools that they have moved to another school. However, this measure is quite accurate in accurately identifying who is and isn't still working at the original school. By comparing individual teacher's values for the Teacher Status variable from SASS with confirmed final turnover from the TFS, we found the Teacher Status variable was about 93\% accurate in distinguishing teachers who had departed from those who had not.

More specifically, the Teacher Status variable from the SASS accurately identified $90 \%$ of confirmed leavers (i.e., 2,385 out of 2,650) as having left the teaching occupation. However, the Teacher Status variable classified 29\% of confirmed movers (i.e., 559 out of 1,911) as having left the teaching occupation, and an additional 1\% of confirmed movers (i.e., 18 out of 1,911) as stayers. When no distinction is made between movers and leavers, the Teacher Status variable was $92 \%$ sensitive (i.e., 4,471 out of 4,886 teachers identified as departing did, in fact, move from or leave their teaching jobs), and Teacher Status was 96\% specific (i.e., 2,442 out of 2,532 teachers identified as not turning over did, in fact, stay in their teaching jobs). This translates to an overall accuracy rate of $93 \%$ (i.e., 6,913 out of 7,418).

In our merger of the SASS and TFS measures, we corrected the Teacher Status measure using TFS data making the former approximately 96\% accurate. Applying the sensitivity and specificity rates above to the uncorrected ATTRIT data (i.e., 40,563 stayers and 3,064 movers/leavers) and assuming 100\% accuracy for those teachers included in the TFS data (i.e., 2,864 stayers and 4,565 movers/leavers), we end up with an overall accuracy rate of 96\% (i.e., $[(40,563 \times .96)+(3,064 \times .92)+(2,864 \times 1.00)+(4,565 \times 1.00)] / 51,056=0.96)$.

ii Especially with an aging teaching workforce, it can be unclear if differences in average salary levels are due to real differences in the compensation offered to comparable teachers at different schools or are due to differences in the experience and education levels of the teachers employed. That is, a school with older teachers may appear to offer better salaries, when, in fact, they do not. A more accurate method of comparison across schools is to compare the normal salaries paid by schools to teachers at common points in their careers. Teacher salary levels are often standardized by school districts according to a uniform salary schedule, based on the education levels and years of experience of the teachers. In this analysis we tested two salary schedule measures - each based on a different point on school salary schedules: 1) the normal yearly base salary for a teacher with 10 years of experience and a masters degree; and 2) the normal yearly base salary for a teacher at the highest possible step on salary schedule. The latter measure had a slightly stronger association with turnover than the former, and it also had relatively fewer missing data; hence, it is used in this study. This measure represents the organizational financial rewards teachers can look forward to at an advanced point in their careers if they stay in their particular schools and, hence, we expect could affect their decisions to depart or stay.

This measure also may have limitations. Some might argue that school salary schedules do not accurately capture the effect of salary on rates of teacher turnover because candidates can 
obtain this information in deciding whether to accept a particular teaching job. From this viewpoint, since public school teachers are compensated according to published salary schedules that change only infrequently, new entrants can predict with almost complete certainty how much they will be paid in each year in the future. Hence, if a teacher did accept a job, it suggests that they are satisfied with their school's salary levels and, hence, most likely low salaries would not be a factor in future turnover.

On the other hand, sometimes teachers may, of course, accept jobs with salaries below what they would prefer and then move in a few years when a better paying job opens up. Goodlad (1984) and others have argued that, while money is not a major factor in teachers' choice of a job, it is a major factor in their decision to move or leave teaching. In this view, beginning teachers are primarily motivated by non-pecuniary and intrinsic values, but if these kinds of expectations are frustrated, salaries can become a source of considerable dissatisfaction. Hence from this viewpoint, salary schedules would be related to turnover precisely because they allow teachers to predict how much they will be paid in the future. This analysis does not presume the validity of either view, but simply tests whether differences in advanced salaries among schools are related to turnover.

iii In Table 4, Table 5 and Figure 3, high-poverty schools refers to those in which $60 \%$ or more of the students are eligible for the federal free or reduced-price lunch program for students from families below poverty level. Low-poverty schools refer to those in which less than $20 \%$ of the students are eligible for the federal free or reduced-price lunch program. High-minority schools refer to those in which $75 \%$ or more of the students are minority. Low-minority schools refer to those in which less than $10 \%$ of the students are minority. Note, these categories represent quartiles of the total SASS sample of public school teachers - these categories are not of equal size in number of schools or students.

iv In Table 5, Serious Student Discipline Problems refers to scores greater than or equal to 3 on a scale of 1 to 5; Inadequate School Leadership Support refers to scores less than or equal to 3 on a scale of 1 to 4; Inadequate School Resources refers to scores less than or equal to 2 on a scale of 1 to 4; Low Faculty Influence refers to scores less than or equal to 2 on a scale of 1 to 4; Low Teacher Autonomy refers to scores less than or equal to 3 on a scale of 1 to 4; Not Useful Discipline-Focused PD refers to scores less than or equal to 1 on a scale of 1 to 4; Not Useful Content-Focused PD refers to scores less than or equal to 2 on a scale of 1 to 4 .

$v \quad$ Note, Figure 5 uses data from both SASS and TFS and hence the percentage rate of turnover differs slightly from Table 6 for 2004-05, which uses TFS data only. In Figure 5 the estimate of inflows is based on the SASS sample and the estimate of outflows is based on the TFS sample. 56,244 leavers represents $10.4 \%$ of the TFS estimate of 540,018 total minority teachers in 2004 , and not $10.4 \%$ of the SASS estimate of 604,749 total minority teachers in the middle of the figure.

vi For our analysis of the destination schools of migrants, we subdivided the total SASS sample of public school teachers into thirdtiles (even thirds) to create high, middle and low categories of schools, according to their poverty and minority enrollments. Low-poverty schools are those with $29 \%$ or less low-income students; high-poverty schools are those with $57 \%$ or 
more. Low-minority schools are those with $22 \%$ or less minority students; high-minority schools are those with $69 \%$ or more.

vii Note that general magnitude of the annual rates of turnover in Figure 6 differ from those in Table 6 and Figure 4 because the former focuses on public schools only, while the latter includes all teachers in both public and private. Moreover, as discussed in the Data/Methods section and in endnote $i$, the regression analyses use a combined TFS/SASS measure of turnover, while the descriptive turnover data in Table 6 and Figure 4 use the TFS measure of turnover. 